\title{
Potential of remote sensing techniques for tsunami hazard and vulnerability analysis - a case study from Phang-Nga province, Thailand
}

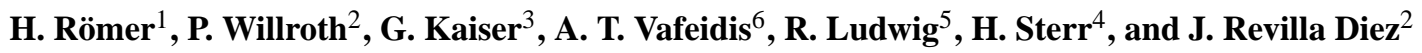 \\ ${ }^{1}$ German Remote Sensing Data Center (DFD), German Aerospace Center (DLR), Oberpfaffenhofen, Germany \\ ${ }^{2}$ Institute of Economic and Cultural Geography, Leibniz University of Hannover, Germany \\ ${ }^{3}$ Norwegian Geotechnical Institute, Oslo, Norway \\ ${ }^{4}$ Institute of Geography, Christian-Albrechts-Universität zu Kiel, Germany \\ ${ }^{5}$ Department of Geography, Ludwig-Maximilians-University, Munich, Germany \\ ${ }^{6}$ Institute of Geography, Cluster of Excellence The Future Ocean, Christian-Albrechts-Universität zu Kiel, Germany \\ Correspondence to: H. Römer (hannes.roemer@dlr.de)
}

Received: 31 December 2011 - Revised: 6 April 2012 - Accepted: 20 April 2012 - Published: 28 June 2012

\begin{abstract}
Recent tsunami disasters, such as the 2004 Indian Ocean tsunami or the 2011 Japan earthquake and tsunami, have highlighted the need for effective risk management. Remote sensing is a relatively new method for risk analysis, which shows significant potential in conducting spatially explicit risk and vulnerability assessments. In order to explore and discuss the potential and limitations of remote sensing techniques, this paper presents a case study from the tsunamiaffected Andaman Sea coast of Thailand. It focuses on a local assessment of tsunami hazard and vulnerability, including the socio-economic and ecological components. High resolution optical data, including IKONOS data and aerial imagery (MFC-3 camera) as well as different digital elevation models, were employed to create basic geo-data including land use and land cover (LULC), building polygons and topographic data sets and to provide input data for the hazard and vulnerability assessment. Results show that the main potential of applying remote sensing techniques and data derives from a synergistic combination with other types of data. In the case of hazard analysis, detailed LULC information and the correction of digital surface models (DSMs) significantly improved the results of inundation modeling. The vulnerability assessment showed that remote sensing can be used to spatially extrapolate field data on socio-economic or ecological vulnerability collected in the field, to regionalize exposure elements and assets and to predict vulnerable areas. Limitations and inaccuracies became evident regarding the
\end{abstract}

assessment of ecological resilience and the statistical prediction of vulnerability components, based on variables derived from remote sensing data.

\section{Introduction}

In recent years the world has been struck by several tsunami disasters. The 2004 Indian Ocean tsunami was one of the deadliest natural disasters ever. In 2009 and 2010 Samoa and Chile respectively were hit by destructive tsunami waves, while in 2011 the east coast of Japan was devastated by the Tohoku Earthquake and subsequent tsunami, the impact of which further led to a nuclear catastrophe. These events highlighted the need for improved methodologies for tsunami risk assessment, management and mitigation. As a consequence in recent years, much effort has been put into the improvement of methods, data and techniques for tsunami risk assessment and for establishing new technologies for tsunami impact mitigation (Strunz et al., 2011; Basher et al., 2006; Post et al., 2008; Taubenböck et al., 2008, 2009). These studies provided comprehensive analyses of tsunami risk, emphasizing the potentials of applying remote sensing techniques as a tool for supporting risk assessment at regional and local scales. However, there are still important challenges in this research field that need to be further addressed: These include, among others, the development of 
transferable methods on the one hand and to improve the accuracy of results derived from remote sensing, on the other hand.

The present study deals with the application of remote sensing in hazard and vulnerability assessment and discusses the potential and limitations resulting from the use of these data on a local scale. The work was carried out in the context of the bilateral research project TRAIT (Tsunami Risks, Vulnerability and Resilience at the Phang-Nga and Phuket provinces, Thailand), in which risk is defined as a combination of hazard and vulnerability of an affected system (Wisner et al., 2004). Thus, the study comprises three parts: (a) an analysis of the tsunami hazard and the analysis of vulnerability of (b) the socio-economic system and (c) the ecological system. Vulnerability is further composed of the three dimensions of exposure, sensitivity and resilience (Turner et al., 2003). Exposure describes the elements in a certain area that are at risk when a specific stress factor impacts upon this area (UNDP-BCPR, 2004). Sensitivity is defined as the degree to which an exposed element is affected by the impact of a natural disaster or external shock (Clark et al., 2000), whereas resilience describes the ability of an exposed element to absorb or resist the impact that could result from a disaster by using available resources and capabilities (UN/ISDR, 2004; Adger et al., 2005). The following three sections provide a short overview on the state of the art regarding the role of remote sensing techniques and data in tsunami hazard and vulnerability analysis.

\subsection{Tsunami hazard analysis}

Numerical tsunami propagation and inundation modeling is a common tool used in tsunami hazard analyses, as it provides information on wave travel time, wave heights, inundation extents, water depths on land as well as current velocities, which are important hazard parameters for damage (potential) analyses. However, to model inundation with a resolution detailed enough for local tsunami risk and vulnerability assessment, very accurate input data regarding tsunami sources, ocean and near-shore bathymetry, topography as well as information on land cover (LC) and obstacles that might influence inundation patterns are required (see e.g. Taubenböck et al., 2009).

Remote sensing has been widely used to generate some of these input data for numerical tsunami inundation modeling and for visualizing and mapping inundation extent (e.g. McAdoo et al., 2007; Schlurmann et al., 2011; Suppasri et al., 2011; Taubenböck et al., 2009). Even beyond tsunami hazard analyses, remote sensing data, and especially remote sensing generated terrain data have been applied, tested and validated in hydrological analyses or in the context of flood modeling at rivers and coasts (e.g. Bates , 2004; Coveney et al., 2010; Haase and Froscher, 2005; Li and Wong, 2010; Mård Karlsson and Arnberg, 2011; Sanders, 2007). These studies showed that the main application of remote sensing data and techniques in hazard analysis is to derive elevation data and to extract LC information, such as vegetation classes or buildings in order to represent the spatial distribution of bottom roughness influencing overland flow.

In the determination of inundation extent and inundation depth in low lying areas, where small changes in topography significantly affect hydrological processes and inundation patterns, the use of accurate topographic data becomes particularly important (Gesch, 2009; Sanders, 2007; Coveney et al., 2010). Many studies have shown that highresolution topographic data are a prerequisite for detailed, local tsunami modeling (Schlurmann et al., 2011; Taubenböck et al., 2009; Kongko et al., 2008; Liu et al., 2002). However, there is also a demand for using and improving elevation models with a lower resolution, since they are relevant for rapid assessments or assessments performed for larger areas. Moreover, they are an important data source where in-situ or high-resolution data are missing (Mård Karlsson and Arnberg, 2011). Therefore, the possibilities of integrating spatial data and numerical models as well as the influence of the spatial resolution, accuracy, and character of different DEMs on tsunami inundation modeling should be explored.

Besides the topography, LC-inducing bottom roughness has shown to significantly influence inundation patterns (Gayer et al., 2010; Jakeman et al., 2010; Kaiser et al., 2011). Remote sensing is supposed to be a useful source to derive land use and land cover (LULC) maps required to account for the spatial distribution of bottom roughness induced by patches of dense vegetation, water bodies, streets or buildings.

\subsection{Socio-economic vulnerability}

For simulating impacts of natural hazards on population, the availability of detailed data on the socio-economic situation, i.e. the distribution of population or economic assets, is crucial. Especially in developing and emerging countries, accurate official data on micro-level are rarely available. In recent years high-resolution remote sensing data offer the possibility to fill this gap. According to Taubenböck et al. (2008), the use of Earth observation data for disaster prevention involving the assessment of socio-economic vulnerability can be still considered as a new and challenging field of research.

The distribution of population is essential information for socio-economic vulnerability assessments. Methods for population estimation based on remote sensing data have been developed since the first aerial photographs were taken. Already in the 1950s, dwelling units were counted for population estimation (Green, 1956) and in the 1980s, Monmonier and Schnell (1984) combined LULC classifications with population information. In general these approaches can be divided into aerial interpolation methods and into statistical modeling methods (Wu et al., 2005). Recent examples can be found in Niebergall et al. (2008) and Taubenböck et al. (2009). Niebergall et al. (2008) used an 
average population value to allocate a number of inhabitants to buildings in informal settlements. Taubenböck et al. (2009) developed a methodology setting up a classification based on housing and location qualification correlating with income as well as property values.

Secondary official statistics to be linked to remote sensing need to be chosen carefully due to the fact that these might not state the actual population number because of nonenforced registration laws. Therefore, approaches that rely on official statistics reflect population numbers that differ from the actual population. Survey data that build on a sample of the actual population should offer a much more accurate support for remote sensing-based analysis of exposure components, such as assets or population numbers compared to the usage of official statistics combined with remote sensing.

\subsection{Ecological vulnerability}

There exists no consistent definition for ecological vulnerability (Williams and Kaputska, 2000; Kumpulainen, 2006; Oliver-Smith, 1996). Birkmann and Wisner (2006) pointed out two major views on ecological vulnerability: a biocentric and an anthropocentric perspective. The bio-centric view, which was also employed in this case study, encompasses the analysis of the fragility and susceptibility of ecosystems and environmental components themselves, whereas the anthropocentric view addresses the disruption of environmental services essential for human well-being, and respectively the inter-linkages between human activities and their needs and ecosystem services and functions (Adger et al., 2005; Birkmann and Wisner, 2006).

There are only few studies where remote sensing techniques have been applied in the context of ecological vulnerability assessments; according to Dahdouh-Guebas (2001) remote sensing can be used to assess ecological impacts, resilience or recovery and thus provide valuable information for assessing ecological vulnerability. He used high resolution imagery to investigate future developments of mangrove vegetation structure and degradation based on vegetation history and current vegetation structure in the field. Wang and $\mathrm{Xu}$ (2009) used multi-temporal image analysis to estimate forest vulnerability to hurricane disturbances. First, they used change detection techniques to assess forest damages; secondly, proxy indicators were defined to identify factors determining the probability of hurricane disturbances. In several studies carried out on a broader scale (e.g. landscapes, riverbasins), remote sensing served as a tool to provide LULC data, which were further analyzed in terms of composition, patterns and landscape metrics (Jones et al., 2003; Li et al., 2006; Zhang et al., 2009).

Regarding the 2004 Indian Ocean tsunami, there has been no study conducted on a comprehensive and spatially explicit analysis of ecological tsunami vulnerability. Most studies deal with the assessment of tsunami impacts on marine and terrestrial ecosystems, particularly mangrove forests

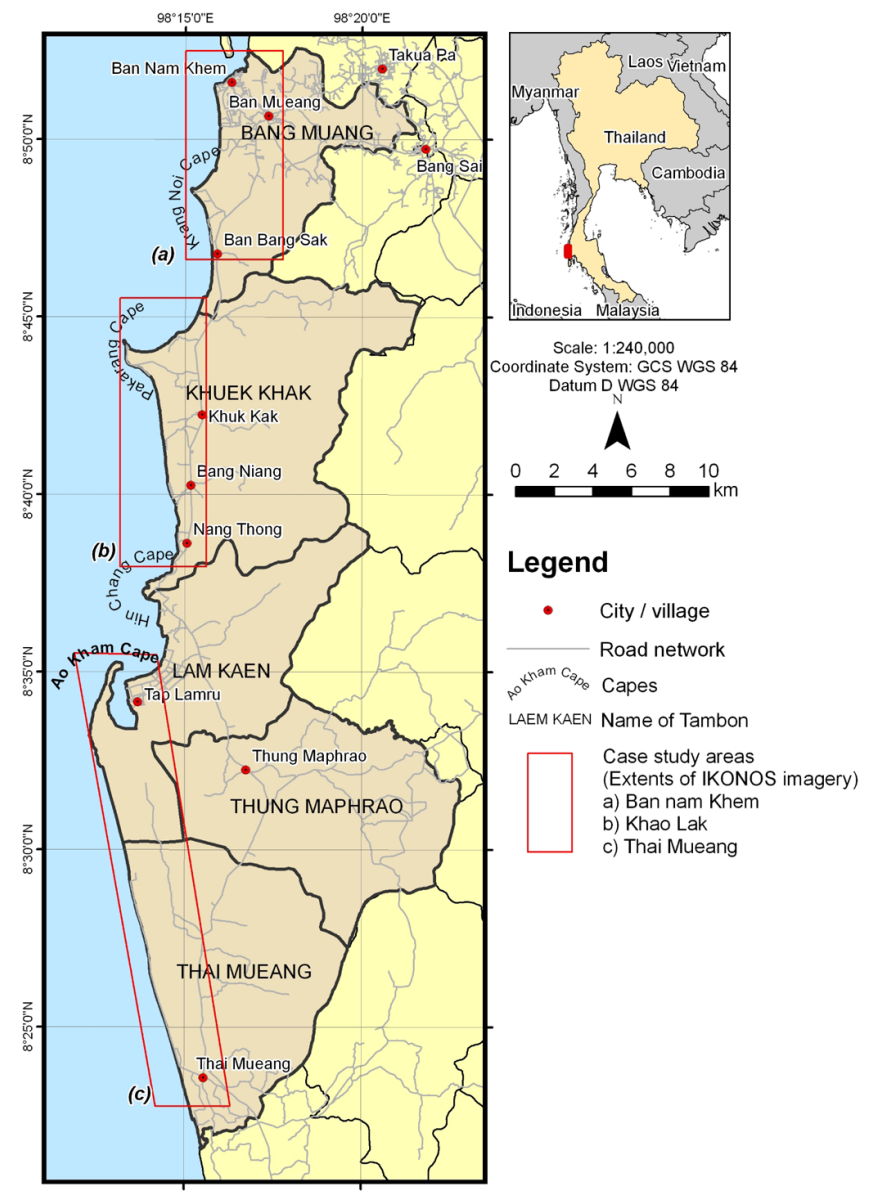

Fig. 1. The study area at the Andaman Sea coast of the Phang-Nga province, Thailand.

(e.g. Sirikulchayanon et al., 2008; Sridhar et al., 2006), coral reefs (e.g. Bahugana et al., 2008) or sandy beaches (e.g. Choowong et al., 2009; Vosberg, 2010). Ecosystem recovery was assessed by Kamthonkiat et al. (2011) and Vu (2008), focusing on mangroves based on ASTER imagery. Chang et al. (2006) and Olwig et al. (2007) evaluated the role of mangrove forests in mitigating tsunami impacts and thus focused on the socio-ecological dimension of vulnerability. Important studies with in-situ data collections on tsunami- induced impacts and recovery of marine ecosystems at the Andaman Sea coast include those of the Department of Marine and Coastal Resources DMCR (2005), Paphavasit et al. (2009) and Fujioka et al. (2008).

\section{Study area}

The study area (Fig. 1) covers a $50 \mathrm{~km}$-long coastal stripe in the Phang-Nga province of Thailand comprising the five Tambons: Ban Mueang, Khuek Kak, Laem Kaen, Thung Maphrao and Thai Mueang. The coastal area was strongly impacted by the tsunami with run-up elevations mostly 
Table 1. Elevation data sets applied in the study.

\begin{tabular}{|c|c|c|c|c|}
\hline & SRTM & ASTER GDEM & MFC DSM & DGPS \\
\hline Type & DSM & DSM & DSM & 31 GCPs \\
\hline System & $\begin{array}{l}\text { Synthetic Aperture } \\
\text { Radar (C-Band-SAR) } \\
\text { data, space-borne, } \\
\text { NASA Endeavour }\end{array}$ & $\begin{array}{l}\text { Advanced Spaceborne } \\
\text { Thermal Emission and } \\
\text { Reflection Radiometer, } \\
\text { NASA Terra }\end{array}$ & $\begin{array}{l}\text { MFC multi-functional } \\
\text { camera MFC-3, DLR }\end{array}$ & Differential GPS \\
\hline Resolution & $\begin{array}{l}\text { Horizontal: } 90 \mathrm{~m} \text { Ver- } \\
\text { tical: } 16 \mathrm{~m} \text { according } \\
\text { to mission } \\
\text { tions } / 6.2 \mathrm{~m}^{*}\end{array}$ & $\begin{array}{l}\text { Horizontal: } 30 \mathrm{~m} \text { Verti- } \\
\text { cal: } 10-25 \mathrm{~m}^{* *}\end{array}$ & $\begin{array}{l}\text { Horizontal: } 0.15 \mathrm{~m} \text { (for } \\
\text { the analysis } \\
\text { interpolated to } 1 \mathrm{~m} \text { ) } \\
\text { Vertical: } 0.50 \mathrm{~m}\end{array}$ & $\begin{array}{l}\text { Random } \\
\text { distribution }\end{array}$ \\
\hline $\begin{array}{l}\text { Acquisition } \\
\text { date }\end{array}$ & February 2000 & 1999 to 2008 & November 2008 & September 2008 \\
\hline Availability & Free & Free & With costs & With costs \\
\hline Spatial scale & Global $\left(60^{\circ} \mathrm{N}-56^{\circ} \mathrm{S}\right)$ & Global $\left(83^{\circ} \mathrm{N}-83^{\circ} \mathrm{S}\right)$ & $\begin{array}{l}\text { Local on demand (area: } \\
66.8 \mathrm{~km}^{2} \text { ) }\end{array}$ & Local on demand \\
\hline Source & $\begin{array}{l}\text { USGS (2004), down- } \\
\text { loaded from the Univer- } \\
\text { sity of Maryland www. } \\
\text { glcf.umd.edu/data/srtm }\end{array}$ & $\begin{array}{l}\text { Product of } \\
\text { METI/NASA through } \\
\text { ERSDAC LP DAAC, } \\
\text { ASTGTM_N08E098 }\end{array}$ & $\begin{array}{l}\text { German Aerospace } \\
\text { Centre (DLR)/ Remote } \\
\text { Sensing Solutions } \\
\text { GmbH (RSS) }\end{array}$ & $\begin{array}{l}\text { Field campaign in } \\
\text { Phang-Nga }\end{array}$ \\
\hline
\end{tabular}

* Rodriguez et al. (2006); ** ASTER GDEM Validation Team (2009).

ranging between 5 to $10 \mathrm{~m}$. The highest values were observed near Khao Lak with 10 to $12 \mathrm{~m}$ and between 8 and $9 \mathrm{~m}$ near Ban Nam Khem. Lower run-up elevations were documented in the south, e.g. at Khao Lampi - Hat Thai Mueang National Park ranging between 3.5 to $6.5 \mathrm{~m}$. Inundation distances varied from a few hundred of meters around Ban Bang Sak and Thai Mueang to more than $1.5 \mathrm{~km}$ near Pakarang Cape (Bell et al., 2004; Ioualalen et al., 2007; Szczucinski et al., 2006; ZKI, 2005).

The region is sparsely populated with 78 people per $\mathrm{km}$. The total population is 41424 . Three major areas can be distinguished: the northern part between Ban Nam Khem and Ban Bang Sak is dominated by the fishing village of Ban Nam Khem and the agriculture sector, whereas the central section with the villages of Khuk Kak, Bang Niang and Nang Thong, known as Khao Lak, is characterized by tourism and large hotel complexes scattered near the coast. The southern part between Tap Lamru and Thai Mueang city hosts large areas of intact coastal ecosystems, like mangrove forests and rain forests which are partial protected by the Khao LampiHat Thai Mueang National Park.

The coastal plains are divided by the foothills of the Phuket mountain range in the east, e.g. between Nang Thong and Tap Lamru. Here, coasts are predominantly rocky with cliff heights of about $50 \mathrm{~m}$ (e.g. Hin Chang Cape). However, west-exposed coasts are mostly built up by sand and are characterized by sequences of beach ridges which often alternate with linear swampy depressions known as swales (Pajimans, 1976). Coasts marked by silty substrates are located near river mouths. The coastal lowland is well-drained by several smaller rivers originating in the Phuket mountain range in the east of the study area (Eichenberg-Suvarnatisha, 1991; Römer, 2011; Willroth, 2012).

\section{Concept and methodology}

\subsection{Data sets}

Different earth observation data sets and derived products were employed. Digital elevation models (DEM) used include data derived from the Shuttle Radar Topography Mission (SRTM), the ASTER Global Digital Elevation Model (ASTER GDEM) and a digital surface model (DSM) derived from stereo image pairs of the Multi-functional camera MFC-3 (MFC). Optical imagery included aerial imagery from the MFC-3 as well as multi-temporal IKONOS imagery. The characteristics of the DEMs and of the 31 ground control points (GCPs), which were used in the context of the tsunami hazard analysis, are described in Table 1.

Pre- and post-tsunami IKONOS data were acquired from the image archives of the Centre of Remote Sensing and Processing (CRISP) at the National University of Singapore (http://www.crisp.nus.edu.sg/) in Singapore and Spatial Dimension Solutions (SDS) in Bangkok (http://www.sd-solution.com/). Pre-tsunami imagery was acquired on 13 January 2003. The acquisition dates of posttsunami images were 15 January 2005 and 20 February 2008. IKONOS images cover three separate areas along 


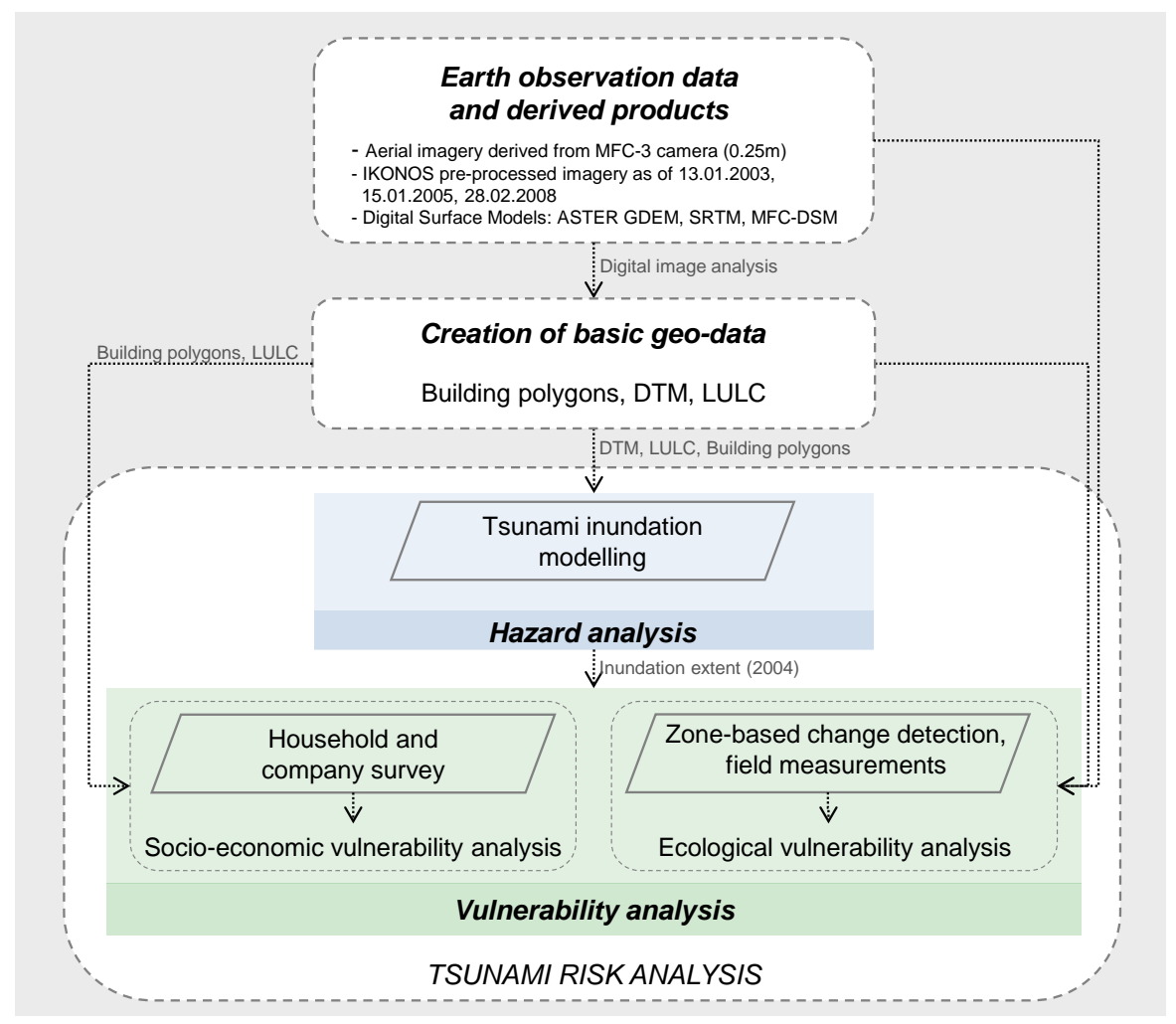

Fig. 2. Methodological concept.

the Andaman sea coast (Sect. 2 and Fig. 1): a northern part $\left(51.55 \mathrm{~km}^{2}\right)$, a central part $\left(60.71 \mathrm{~km}^{2}\right)$ and a southern part $\left(84.47 \mathrm{~km}^{2}\right)$. Due to a limited availability of cloud-free images for the third acquisition date, no imagery was acquired for the southern area between Tap Lamru and Thai Mueang. Image pre-processing steps included the derivation of at sensors aperture radiance values $\left(\mathrm{W} \mathrm{m}^{-2} \mu \mathrm{m}^{-1} \mathrm{sr}^{-1}\right.$ ) from the image products (Taylor, 2009), co-registration, pansharpening and atmospheric correction (dark object subtraction) and are further described in (Römer et al., 2011).

\subsection{General approach}

With regard to the general workflow (Fig. 2), remotely sensed data and derived products were employed at different steps. At first, basic geo-data including building polygons, LULC as well as digital terrain models (DTM) were created from the input data sources. These derived basic geo-data sets served as basic input for the three case studies on the analysis of tsunami hazard (Sect. 3.4) and of socio-economic and ecological tsunami vulnerability (Sects. 3.5 and 3.6).

The presented methods on the assessment of socioeconomic and ecological vulnerability (Sects. 3.5. and 3.6) are referring to a large extent to the work that has been conducted and published within the TRAIT project. Therefore, the respective sections provide a short description of the methods employed. Further details on the methodology can be found in Willroth (2012) for the socio-economic vulnerability and in Römer (2011) for the ecological vulnerability.

\subsection{Generation of basic geo-data}

\subsubsection{Generation of detailed LULC information}

A LULC classification map was generated from the pretsunami IKONOS images using a rule-based object-oriented image classification approach. In total 38 LULC classes were distinguished, including terrestrial coastal ecosystems (e.g. mangrove forests, different types of coastal forests), agricultural area (e.g. coconut and rubber plantations), barren land and built-up area. Two hierarchical levels were applied for segmentation and classification: a lower level was used to classify small landscape objects, including single trees, tree shadows and buildings. A higher level was used to classify the different LULC classes. Sub-level information (e.g. relative area of sub-objects classified as class $\mathrm{X}$ ) was applied in the upper level to extract high textured classes, such as coconut plantations or urban areas. Several image segmentation steps were carried out in the higher level, whereas segmentation settings were adjusted to the respective classes to be extracted. This approach led to a typical sequence of processing steps: (a) image segmentation, (b) classification of one or more classes using the rule set, (c) merging of unclassified 
Table 2. LULC class heights and ground coverage derived from field measurements at the Phang Nga coast. The last column included the calculated LULC class offset to be subtracted from the original SRTM data.

\begin{tabular}{|c|c|c|c|c|}
\hline Super class & Sub-class & $\begin{array}{l}\text { Measured average } \\
\text { LULC class height } \\
\text { - Lh }(\mathrm{m})\end{array}$ & $\begin{array}{l}\text { Average crown } \\
\text { ground cover } \\
-n(\mathrm{~m})\end{array}$ & $\begin{array}{l}\text { Average LULC } \\
\text { offset }(\mathrm{m})(\mathrm{Lh} \times n)\end{array}$ \\
\hline \multirow[t]{8}{*}{ Agriculture } & Aquaculture reservoirs & 0.00 & 0.00 & 0.00 \\
\hline & Cashew nut plantation & 10.00 & 0.50 & 5.00 \\
\hline & Coconut plantation & 13.00 & 0.60 & 8.00 \\
\hline & Oil palm plantation & 9.00 & 0.95 & 8.55 \\
\hline & Other plantation & 10.00 & 0.50 & 5.00 \\
\hline & Prepared land & 0.00 & 0.00 & 0.00 \\
\hline & Rubber plantation & 25.00 & 0.65 & 16.00 \\
\hline & Young plantation & 1.00 & 0.10 & 0.10 \\
\hline \multirow[t]{3}{*}{ Barren land } & Coastal mudflats & 0.00 & 0.00 & 0.00 \\
\hline & Sandbanks. beaches & 0.00 & 0.00 & 0.00 \\
\hline & Sparsely covered land & 0.00 & 0.00 & 0.00 \\
\hline \multirow[t]{4}{*}{ Forest } & Casuarina forests & 30.00 & 0.60 & 18.00 \\
\hline & Mangrove forest & 7.00 & 1.00 & 7.00 \\
\hline & Natural rainforest & 40.00 & 0.80 & 32.00 \\
\hline & Secondary forest & 19.00 & 0.80 & 15.00 \\
\hline \multirow[t]{3}{*}{ Open landscape } & Grassland* & $0.10 / 25.00$ & $0.95 / 0.005$ & 1.35 \\
\hline & Open woodland & 12.00 & 0.50 & 6.00 \\
\hline & Scrubland & 1.50 & 0.75 & 1.10 \\
\hline \multirow[t]{5}{*}{ Built-up land } & Built-up high density & 6.00 & 0.80 & 4.80 \\
\hline & Built-up low density & 6.00 & 0.50 & 3.00 \\
\hline & Plantations buildings & 6.00 & 0.80 & 4.80 \\
\hline & Roads & 0.00 & 0.00 & 0.00 \\
\hline & Shrimp farm industry & 6.00 & 0.90 & 5.40 \\
\hline Water & Ponds, streams & 0.00 & 0.00 & 0.00 \\
\hline
\end{tabular}

* grassland is mostly interspersed with single medium tall trees with heights of about $25 \mathrm{~m}$ with an average ground cover of 0.05 .

segments and (d) a new segmentation of the merged unclassified segments. The entire rule set consists of 21 single segmentation steps (16 multi-resolution and five chessboard segmentations) and is further described in Römer et al. (2011). With an overall accuracy of $93.60 \%$ and a Kappa of 0.90 , the classification accuracy can be regarded as high. Furthermore, LULC data and geo-coded photos were collected during a mapping campaign conducted between October and December 2008. The photos were used for verifying LULC classification as well as results derived from change detection (Sect. 3.6).

\subsubsection{Creation of DTMs}

Three elevation data sets were prepared from the original SRTM, ASTER GDEM and MFC raster data for use in tsunami inundation modeling. All three DEMs face some limitations for inundation modeling, since they are digital surface models (DSMs), which include vegetation and settlement structures in their height description (Gesch, 2009; Hofton et al., 2006; Hirt et al., 2010; Sun et al., 2003,
Weydahl et al., 2007). This may lead to incorrect inundation extents and water depths. Hence an analysis and quantification of the offset and its influence are necessary (Coveney et al., 2010).

Preliminary inundation simulations with the original data sets for our study areas showed that significant height offsets of up to $20 \mathrm{~m}$ occurred in the SRTM and MFC data, where patches of tropical forest are located. As this influenced or even inhibited the accurate estimation of inundation during modeling, elevation offsets resulting from landscape objects such as trees, or buildings had to be removed. Due to the structure of the data sets, different methodologies for DSM correction were applied. As there is an interrelation between LULC heights and the SRTM height values (Gallant and Hutchinson, 2006), the SRTM was corrected using LULC information (Ludwig and Schneider, 2006; Lohmann and Jacobsen, 2004). To correct the SRTM data set to a "bare ground model", the LULC classification, based on 2003 pre tsunami IKONOS imagery (see Sect. 3.3.1), was used and LULC heights, density and crown coverage (in case of trees) were measured in a field campaign (Table 2). Mean height 


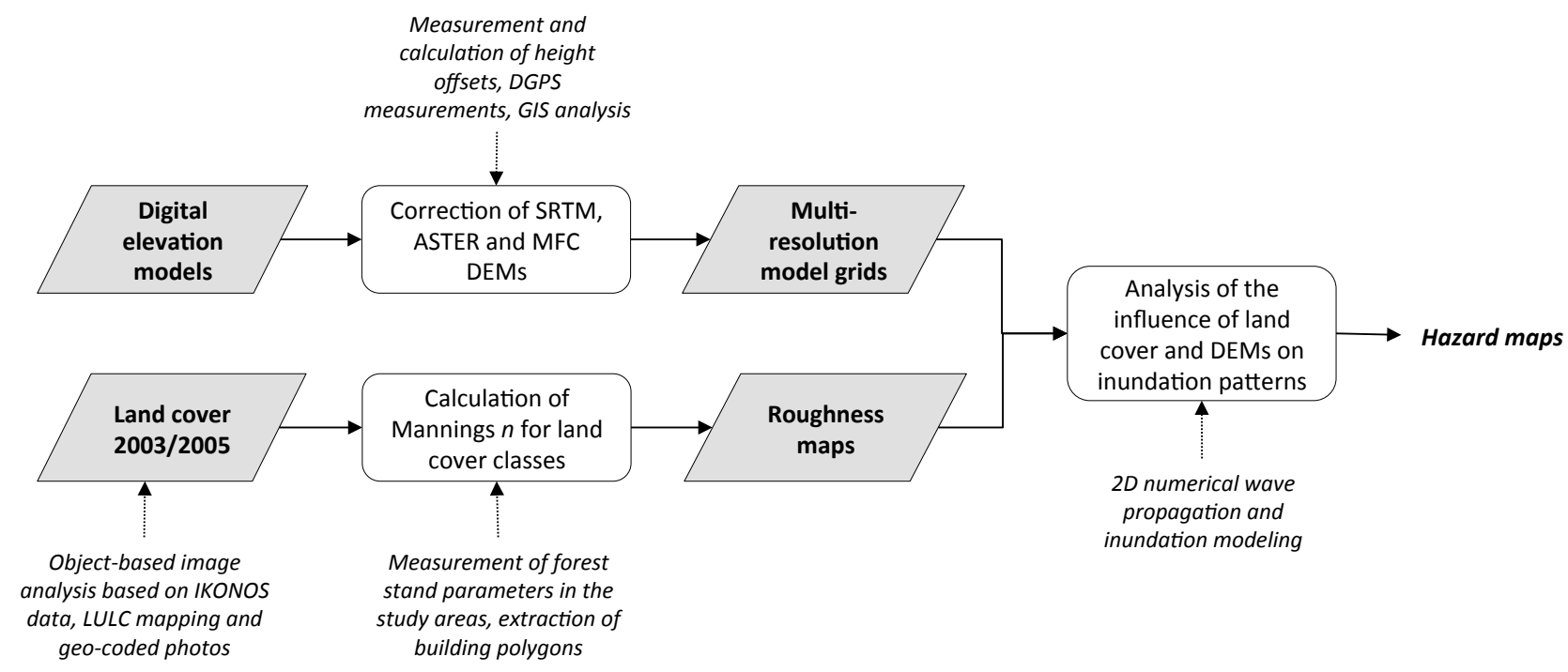

Fig. 3. Workflow and remote sensing application in the hazard analysis.

values for every LULC class multiplied with the ground coverage were added to the LULC classification in a GIS. The final LULC map was then converted into a raster, resampled and eventually subtracted from the SRTM data according to Eq. (1). Finally, the DTM-raster was smoothed using a fillfilter algorithm (ESRI ArcGIS).

$h \_$SRTM_corrected $=h \_$SRTM $-h(\mathrm{Lh}) \times n$, res.

where $\mathrm{Lh}=$ land cover height, $n=$ average crown ground coverage, and res. $=$ resolution.

A correction of the ASTER GDEM with LULC information was not carried out. Although deviations from the real ground elevation were obvious also in the ASTER GDEM, no systematic height offset due to LULC could be observed in the original data set in our case study. To correct the MFC DSM, GCPs were selected based on visual interpretation of the MFC DSM and the corresponding RGB-imagery and interpolated using the inverse distance algorithm. Only locations that represent the land surface were used for GCP selection. This method is very transparent and provides promising results if the point density is high. This manually created MFC data set has an average point density of 45 points per $0.01 \mathrm{~km}^{2}$. The corrected MFC, hereafter called MFC $\mathrm{DEM}_{\text {ref }}$, has been used as a reference elevation model in this work, since it turned out to be the most accurate elevation data set available for this study. The resolution was set from $0.15 \mathrm{~m}$ to $1 \mathrm{~m}$, as this represented the best compromise between processing speed and detailed representation of the surface.

Finally, the following five data sets were used as input for the inundation model: SRTM $(90 \mathrm{~m})$, SRTM_corrected $(90 \mathrm{~m})$, ASTER GDEM $(30 \mathrm{~m})$, MFC $(1 \mathrm{~m})$, and MFC $\operatorname{DEM}_{\text {ref }}(1 \mathrm{~m})$.

\subsubsection{Extraction of building polygons}

Building polygons for the area between Ban Nam Khem and Nang Thong (Fig. 1) were derived from the MFC aerial imagery based on visual image interpretation and manual digitizing. Furthermore, an automatic approach using objectoriented image analysis was conducted within the project. However, due to limitations in the geometric accuracy of the extracted single buildings, the results were not used in this study. The automatically extracted polygons overestimated the built-up area by nearly $30 \%$ in Ban Nam Khem.

\subsection{Hazard analysis}

The overall aim of the hazard analysis was to provide information on key parameters of the inundation process, such as inundation extent, water depth, flow velocities and fluxes, serving as a basis for tsunami risk and vulnerability assessment. To simulate and map inundation patterns, numerical tsunami modeling was performed by combining source and wave propagation modeling with NOAAs ComMIT tool (Titov and Synolakis, 1995, 1998) and inundation modeling with MIKE 21 Flexible Mesh (DHI, 2009; www.mikebydhi. com). In ComMIT predefined source units were used and adapted to the source mechanisms of the 2004 tsunami as well as for possible future scenarios for Thailand, according to Løvholt et al. (2006). Tsunami wave generation, propagation and inundation were then modeled by connecting ComMIT and MIKE 21 at an open boundary. Validation of the modeled inundation was performed by comparing the results to run-up measurements from a field survey team (Thailand Group, 2005). Details on the tsunami modeling, the boundary 


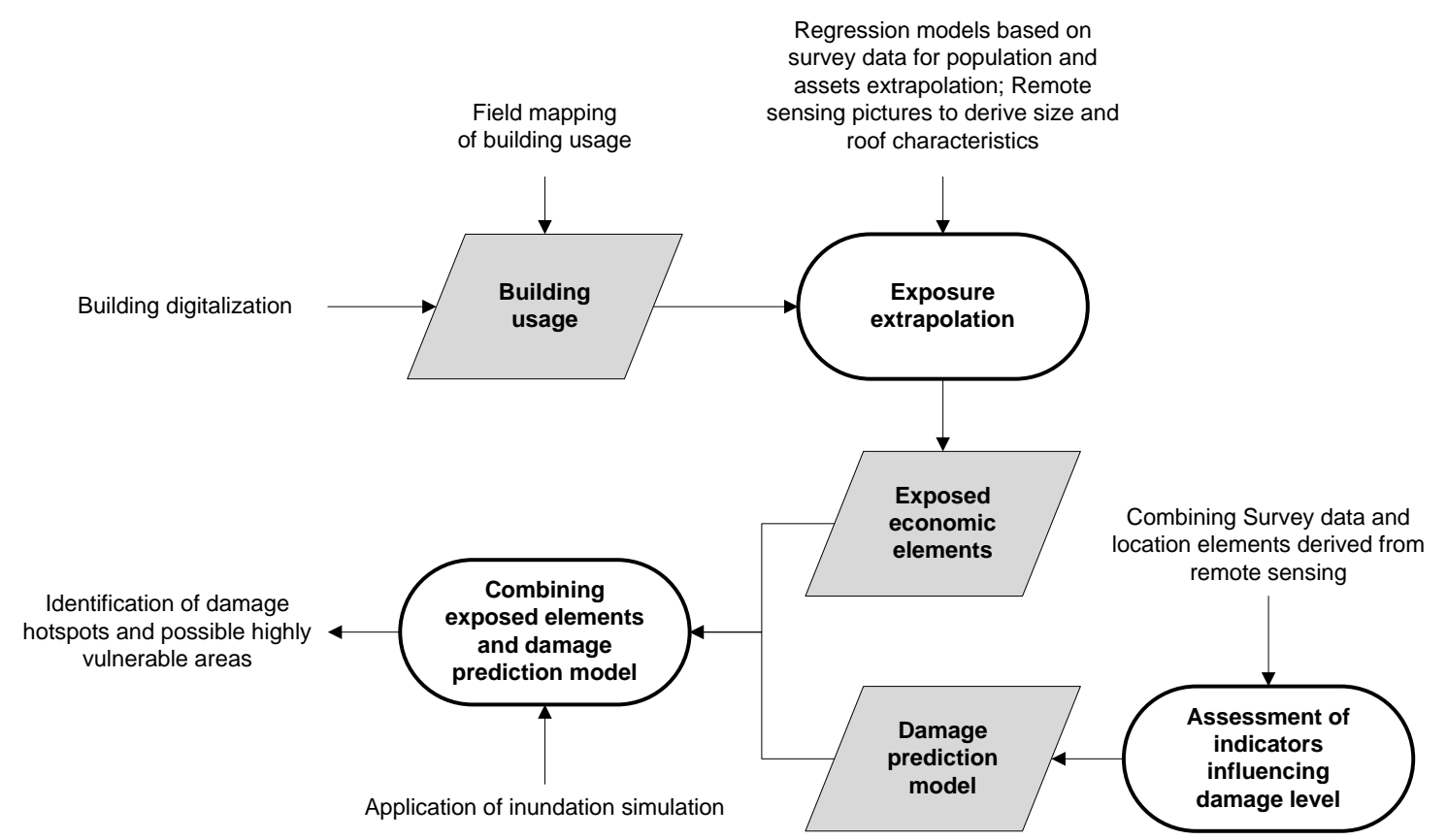

Fig. 4. Methods used to identify vulnerable areas.

conditions and grids as well as validation can be found in Kaiser et al. (2011) in this issue.

The first step in inundation modeling included the preparation of model grids from the different elevation data sets (see Fig. 3). The resolution of the flexible meshs in MIKE21 was chosen according to the resolution of the elevation data. However for the MFC and the MFC DEM $\mathrm{Def}_{\text {, }}$, the resolution had to be reduced to $10 \mathrm{~m}$ (MFC) and $7 \mathrm{~m}\left(\right.$ MFC DEM $\left._{\text {ref }}\right)$ for computational reasons. For the former a coarser resolution of $10 \mathrm{~m}$ was necessary due to steep gradients occurring at the borders of landscape objects in the DSM leading to instabilities in the simulations. The final model grids were SRTM $90 \mathrm{~m}$, SRTM_corrected $90 \mathrm{~m}$, ASTER GDEM $30 \mathrm{~m}$, MFC $10 \mathrm{~m}$ (based on $1 \mathrm{~m}$ ) and the reference model MFC $\mathrm{DEM}_{\mathrm{ref}} 7 \mathrm{~m}$ (based on $1 \mathrm{~m}$ ). As the study area is characterized by dense coastal vegetation, bottom roughness was deemed to be important and was incorporated in the numerical model. To also account for changes in LULC, a LULC classification from 2003 and a LULC change map from 2005 were included. Bottom roughness was assessed by assigning Manning values calculated from field measurements and derived from literature (see Kaiser et al., 2011) to LULC data. As single buildings were not included in the LULC map of 2003, the extracted building polygons (Sect. 3.3.3) were incorporated afterwards and high roughness values were assigned to the building polygons (according to Gayer et al., 2010, see Kaiser et al., 2011).

\subsection{Socio-economic vulnerability analysis}

Figure 4 illustrates the workflow applied to analyze socioeconomic vulnerability. Due to the lack of data available at micro-level, surveys were conducted in Khao Lak and Ban Nam Khem. The households and companies were interviewed using a questionnaire that included questions on socio-economic or business status, exposed assets, additional information on the tsunami impact and on building information. This information was geocoded to connect it with remote sensing data. In the two study areas, 170 households were interviewed representing around $6 \%$ of the total population, and 103 companies, representing $20 \%$ of the total population. The totality of usage of buildings (exclusively commercial/exclusively residential building/mixed use) was assessed during a field mapping campaign (exclusively commercial/exclusively residential building/mixed use).

First, a pre-analysis based on the survey data was conducted to assess if housing classes could be set up according to the type of houses clustered together or if each building has to be investigated separately. Therefore, Moran's index as a measurement tool for spatial autocorrelation was used. Moran's index showed significant random results for all socio-economic input variables (Dray, 2011). These findings led to the conclusion that no spatial and social segregation among the households in the villages of Ban Nam Khem and Khao Lak exists. In the following each house was investigated separately. It was tested whether the socio-economic characteristics of one household are correlated with any 
Table 3. Regression model for household assets (own calculations based on TRAIT household survey).

\begin{tabular}{|c|c|c|c|c|c|}
\hline \multicolumn{2}{|c|}{ Population } & \multicolumn{2}{|c|}{ Household income } & \multicolumn{2}{|c|}{ Household assets } \\
\hline Constant & 2.333 & Constant & 25528.1 & Constant & 189392.6 \\
\hline Size of house & $\begin{array}{r}0.013 \\
(0.331)\end{array}$ & Gray roof & $\begin{array}{r}-17858.0 \\
(-0.32)\end{array}$ & Size of house & $\begin{array}{r}1388.3 \\
(0.51)\end{array}$ \\
\hline \multirow[t]{2}{*}{ Gray roof } & $\begin{array}{r}0.997 \\
(0.349)\end{array}$ & $\begin{array}{l}\text { No. of house- } \\
\text { hold members }\end{array}$ & $\begin{array}{r}2302.8 \\
(0.18)\end{array}$ & Gray roof & $\begin{array}{r}-62650.7 \\
(-0.10)\end{array}$ \\
\hline & & & & Household income & $\begin{array}{r}2.58 \\
(0.30)\end{array}$ \\
\hline corr. $R^{2}$ & 0.202 & corr. $R^{2}$ & 0.12 & corr. $R^{2}$ & 0.38 \\
\hline
\end{tabular}

Beta values in brackets, variables significant at $5 \%$ level $-n=170$.

Table 4. Prediction model for asset damage.

\begin{tabular}{lccccccc}
\hline & \multicolumn{3}{c}{ Households* } & & \multicolumn{3}{c}{ Companies** } \\
\cline { 2 - 3 } & $\begin{array}{c}\text { Standardized } \\
\text { Path-coefficient }\end{array}$ & $f^{2}$ & Corr. $R^{2}$ & & $\begin{array}{c}\text { Standardized } \\
\text { Path-coefficient }\end{array}$ & $f^{2}$ & Corr. $R^{2}$ \\
\hline Assets & 0.25 & 0.09 & 0.27 & & 0.69 & 0.99 & 0.52 \\
Location & -0.47 & 0.3 & & & -0.11 & 0.03 & \\
\hline * Durbin-Watson: 2.07; Variance Inflation Factor: $1.00-n=170 ; * *$ Durbin-Watson: 2.08; Variance Inflation Factor: \\
1.01 - $n=199$.
\end{tabular}

characteristics of the dwelling unit (Wu et al., 2005). Solely indicators applicable by remote sensing were used.

Information on the "net dwelling area" of each building was derived from the MFC data using the building shapes. Building height was calculated by dividing the difference of

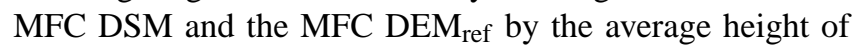
a storey. The roofing material was used as a second supporting indicator for the assessment of socio-economic indicators. The MFC aerial imagery was used to define roof color. Survey data showed that households living in houses with Gray roofs made of corrugated iron sheets have a significantly lower accumulation of consumable assets. Based on these findings, a regression model was developed by correlating socio-economic household characteristics and remote sensing indicators at the spatial level of dwelling units. Especially for houses with Gray roofs, the predicted number of household members increased strongly by nearly one more person. The household assets were calculated based on the distribution of population and the socio-economic status that was estimated through remotely sensed data (Table 3 ).

Additionally, the business sector of the area was assessed. In terms of direct exposure, household income and property values were evaluated. Due to the limited sample size and the heterogeneity of the companies, six different business sectors were distinguished. Physical assets were allocated by creating percentile classes based on the survey data. These percentile classes were linked to significantly differing building sizes and to the business sector.

For the damage prediction, building shapes were combined with locational factors (height above mean sea level and distance from the coastline) of the potentially affected households and companies (Ruangrassamee et al., 2007; Reese, 2003). Long-term consumable assets and property values form the total amount of assets.

Covering the setting in the study area, specific damage prediction functions were developed using a structural equation model (Willroth et al., 2011; Smith, 1994). This method allowed regressing formative factors set up by indicators. Pretsunami assets and the location (ma.s.l., Distance to coastline in meters) were regressed on the 2004 tsunami damage (Table 4). Separate models for the households and companies were developed (Willroth, 2012). These models were applied to all households and companies in the study regions in order to create a map of the regional distribution of tsunami damage.

\subsection{Ecological vulnerability analysis}

Ecological vulnerability was assessed using multi-temporal IKONOS imagery combined with data collected during field investigations. The idea was to retrospectively assess the tsunami-induced impacts and recovery patterns of the 
exposed ecosystems for the 2004 tsunami, in order to better understand spatial characteristics of tsunami vulnerability and to estimate their main determining factors (Fig. 5).

The exposure analysis involved the identification and regionalization of exposed ecosystems. First, valuable coastal ecosystems were defined based on expert judgment and field visits carried out in September 2007 and March 2008. Mangrove forests, casuarina beach forests, coconut plantations, mixed beach forests and melaleuca forests were selected as exposure units, due to their representativeness of the tropical coastal areas of Southeast Asia and their importance in providing essential ecological functions and services to the human and natural system (Chatenoux and Peduzzi, 2007; MEA, 2005, Paphavasit et al., 2009; Plathong et al., 1997). The ecosystems were regionalized using the LULC classification derived from IKONOS pre-tsunami imagery. The exposed areas were then identified based on the inundation map of the 2004 Indian Ocean tsunami (Sect. 3.4).

Tsunami sensitivity and resilience were estimated using a dual fold approach: first, change detection techniques and field investigations were used to assess tsunami-induced impacts and recovery patterns of the affected ecosystems. Second, change detection results were related to a set of independent variables in order to identify the determining factors of the spatial variability of these vulnerability proxies. The direct multi-date classification (DMC) and the change vector analysis (CVA) were used for the assessment of impacts. Whereas the CVA was based on the first two tasseled cap components greenness and brightness, the DMC involved a supervised maximum-likelihood classification using the red, green and near infra-red multi-spectral bands from both acquisitions dates (Horne, 2003; Johnson, 1994; Mas, 1999). According to Clark et al. (2000) and Pimm (1991), ecosystem recovery can be regarded as a measure of resilience and is defined as the rate and potential at which ecosystems reclaim their habitats by natural succession after being destroyed or removed by a tsunami. A combined approach of the CVA, as well as a vegetation recovery rate, were derived from the ratio of the two TNDVI differences (Transformed Normalized Vegetation Index) of two later and two earlier acquisition dates (2008 and 2005, respectively 2003 and 2005). Training and test pixels used for accuracy assessments were selected from the pansharpened IKONOS imagery. In-situ data on vegetation recovery were collected in March and April 2009 and used to develop change detection methods and to interpret change detection results. Quantitative vegetation structure data of saplings in the examined ecosystems were collected, e.g. average diameter at knee height $(\mathrm{m})$, stand height $(\mathrm{m})$, stand density $\left(\mathrm{ha}^{-2}\right)$ or ground cover of seedlings/saplings species were collected. Qualitative data comprised information on the tsunami impact, $\mathrm{LU}$ history, soil texture and community structure before and after the tsunami (Römer et al., 2011).

A next step included the statistical relation of change detection results to a set of independent variables. The approach included correlation statistics and linear regression models. The following variables were considered:

- Hazard variables: maximum total water depth above ground $D_{\mathrm{G}}(\mathrm{m})$ and maximum current speed $S_{\mathrm{C}}\left(\mathrm{m} \mathrm{s}^{-1}\right)$,

- Location variables: elevation above sea level $E(\mathrm{~m})$, distance to shoreline $D_{\mathrm{S}}(\mathrm{m})$, distance to rivers $D_{\mathrm{R}}(\mathrm{m})$, depth of topographic sinks $S$ (m), inclination or geographic orientation of coastline $I\left(^{\circ}\right)$, intensity of human activities after the tsunami $H(\%)$,

- disturbance variable, $A_{\mathrm{D}}(\%)$ to characterize the initial environmental conditions subsequently after the tsunami impact,

- exposure unit variable, which represents the pretsunami state of vegetation structure, e.g. the forest age or stand density. Due to missing pretsunami in-situ data, the NDVI (NDVI) of the year 2003 image was used as a proxy indicator (Lu et al., 2006; Freitas et al., 2005).

In order to evaluate the role remote sensing can play in identifying vulnerable areas in advance of a tsunami disaster, it was necessary that the independent variables can in principle be observed by Earth observation data. This basic requirement applies to $I, H, D_{\mathrm{S}}, D_{\mathrm{R}}$ (in this study derived from available data layers), $E$ and $S$ (based on the MFC $\left.\mathrm{DEM}_{\mathrm{ref}}\right) . A_{\mathrm{D}}$, NDVI and the two dependent variables, impacts and recovery were directly derived from satellite imagery. Hazard variables, which were derived from inundation modeling, hold a strong causal or direct physical relationship to the observed tsunami impacts and thus were mainly used for verification purposes. $E, S, I, D_{\mathrm{S}}, D_{\mathrm{R}}, D_{\mathrm{G}}, S_{\mathrm{C}}$, and NDVI were considered for the impact assessment, whereas $E, S, D_{\mathrm{S}}, D_{\mathrm{R}}, H$, and $A_{\mathrm{D}}$ were used for the recovery analysis. All variables were quantitatively represented on uniform quadratic $30 \times 30$-m grid cells.

\section{Results}

\subsection{Hazard analysis}

Comparing the five DEMs used for tsunami inundation modeling, significant differences could be observed mainly due to a LULC offsets (Fig. 6). A profile taken in the study area demonstrates the LULC offset in the SRTM, SRTM_corrected, ASTER GDEM and MFC compared to the

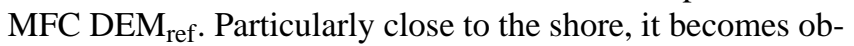
vious how coastal forests exaggerate the terrain and thus inhibit inundation simulation in the model.

For a spatial comparison of the different elevation models, an accuracy assessment was performed for the original SRTM, the SRTM_corrected, the ASTER GDEM and the MFC. The data sets were compared to the measured DGPS 


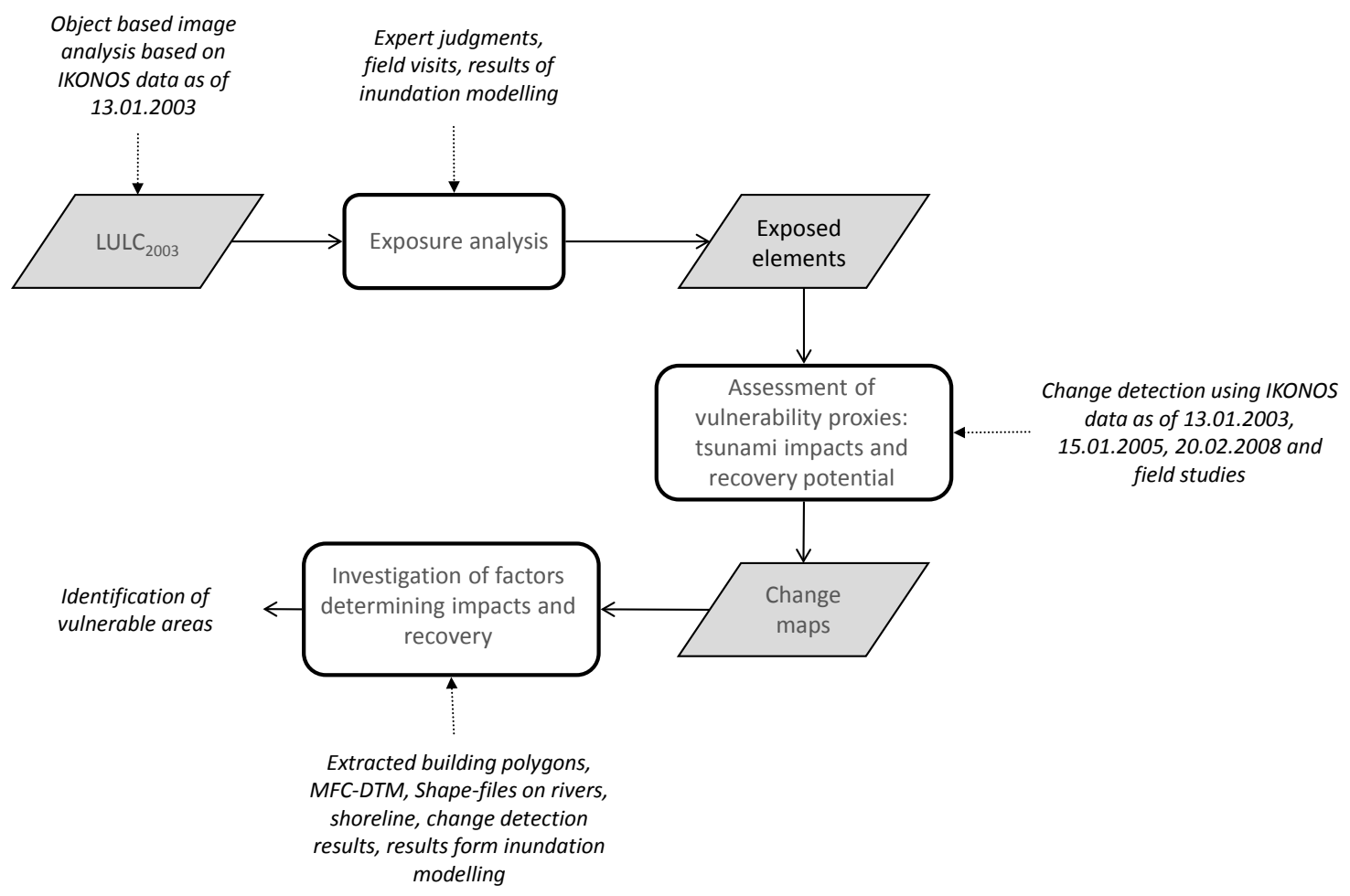

Fig. 5. Workflow applied to analyze ecological vulnerability.

points and to the MFC DEM ${ }_{\text {ref }}$, since the DGPS points were located along streets only. A randomly chosen, equal number of points were chosen from both data sets (DGPS and

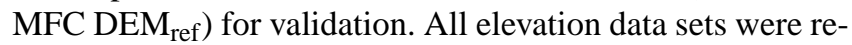
sampled to $1 \mathrm{~m}$ resolution in order to derive comparable results, and nearest neighbor resampling was applied in order to keep the original values of the raster data sets. Then, for each point the DGPS elevation values and the MFC DEM $M_{\text {ref }}$ values were subtracted from the corresponding DEM pixel value to calculate the error (Ludwig and Schneider, 2006). For the original SRTM data, an RMS error of $7.81 \mathrm{~m}$ (Fig. 7) could be observed. This value compares well with the findings of Gorokhovich and Voustianiouk (2006) and their study for Phuket, Thailand as well as with the analyses by Falorni et al. (2005). The correction of the SRTM data improved the elevation model significantly to an RMS error of $3.62 \mathrm{~m}$, indicating that the procedure of correcting SRTM data by LULC information (see Sect. 3.3.1) was useful in our case. This needs to be confirmed for other areas. The correction performed best in homogenous vegetation patches of high density, e.g. mangrove forests. The error statistics for the ASTER GDEM reveal a lower RMSE of $3.92 \mathrm{~m}$. Due to the high resolution, MFC accuracy was high along streets, but high elevation offsets occurred in vegetated areas.

A comparison of the inundation maps based on the different elevation models (Table 5 and Fig. 8) shows that the inundation extent and water depths vary significantly for the same
Table 5. Extent of the inundated area using different elevation models for the Khao Lak area.

\begin{tabular}{lr}
\hline Elevation model & Flooded area $\left(\mathrm{m}^{2}\right)$ \\
\hline SRTM $(90 \mathrm{~m})$ & 166860 \\
SRTM_corrected $(90 \mathrm{~m})$ & 12773700 \\
ASTER GDEM $(30 \mathrm{~m})$ & 13180500 \\
MFC $(10 \mathrm{~m})$ & 6472600 \\
MFC DEM $_{\text {ref }}(7 \mathrm{~m})$ & 14510125 \\
\hline
\end{tabular}

inundation scenario but with different underlying elevation models. In Khao Lak the model run with the original SRTM data led to almost no inundation. The inundated area amounts to $166860 \mathrm{~m}^{2}$ compared to the reference inundation from the simulation with the MFC DEM ref area of $14510125 \mathrm{~m}^{2}$. This means that only $1.15 \%$ of the actually flooded area could be reconstructed when using the uncorrected SRTM data. The reason for this is the dense vegetation along the coast (mainly casuarina forests, mangroves and plantations), which acts as a barrier, inhibiting inundation during modeling when represented in the $90 \mathrm{~m}$ resolution. Only in large tidal inlets (large enough to be covered by a $90 \mathrm{~m}$ SRTM raster cell) inundation could be simulated. An underestimation of inundation when using the SRTM has also been observed in other studies. For example Li and Wong (2010) conducted river flood simulations based on SRTM, LIDAR 


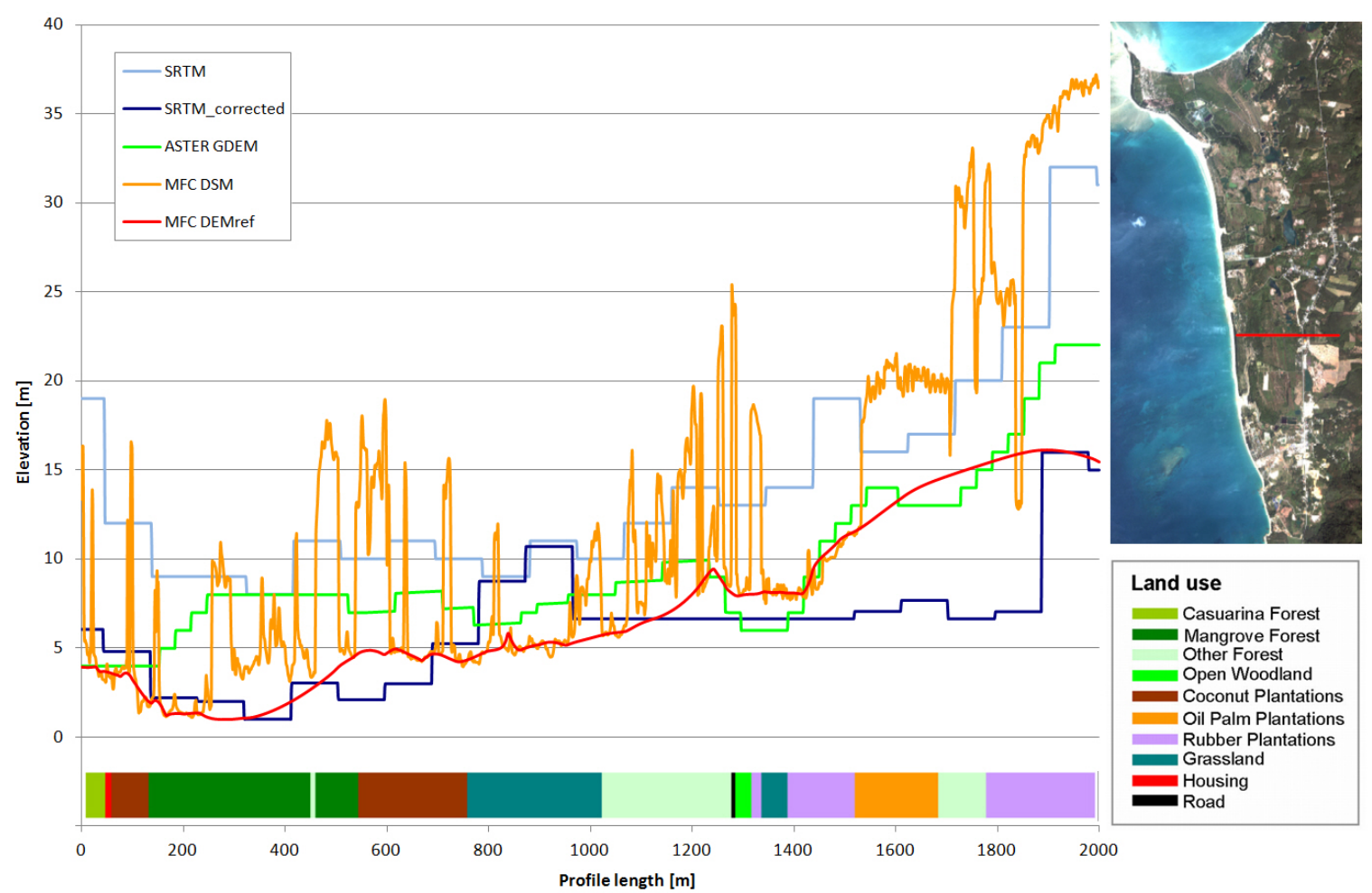

Fig. 6. Cross section showing the height offsets due to LULC for the different elevation models.

and NED data and found that inundation areas based on the SRTM cover only $60 \%$ compared to the other DEMs. In contrast, for the SRTM_corrected, the simulated inundation extent is much closer to the reference inundation, with an inundated area of $12773700 \mathrm{~m}^{2}$ ( $88 \%$ of the reference area).

The modeled inundation, based on the ASTER GDEM run, produced good results regarding the inundation extent $\left(13180500 \mathrm{~m}^{2}\right.$, or $90.83 \%$ of the reference area). However, a difference image (Fig. 9) between the ASTER GDEM inundation and the reference inundation shows that the distribution of water depths is not conforming to the reference inundation. It has to be taken into account that the ASTER GDEM contains artifacts (ASTER GDEM Validation team, 2009) that reduce its overall accuracy and cause restrictions for the application in inundation modeling.

Even the modeled inundation based on the high resolution MFC data is quite small, covering only $44.60 \%$ of the reference inundation. As with the SRTM this is due to vegetation and buildings acting as barriers. Due to the high resolution of the elevation data, water penetration through landscape objects, such as single buildings, single trees or small groups of trees could be modeled, so that at least some flooding occurs. For the inundation extent it can be concluded that in the study areas corrections of SRTM and MFC DSMs are necessary to produce realistic inundation results. This is believed to be the same in all areas, where coastal forests dominate the landscape. In our case the ASTER GDEM produced promising results regarding the inundation extent. However, in order to assess the accuracy of the inundation based on the ASTER GDEM, this result needs to be confirmed in other study areas, due to the known limitations described above.

Simulations including the pre-tsunami roughness maps based (2003) and the post-tsunami (2005) LULC change map showed a slight influence of the LULC change on inundation depths and extents and strong influence on flow velocities. A detailed analysis of flow dynamics in the mangrove forest at Pakarang Cape showed that flow velocities increase significantly by up to $50 \%$ after the Manning values had been adjusted to mangroves, which were destroyed by the tsunami (Kaiser et al., 2011). Changes in inundation patterns, i.e. mainly flow velocities, could also be observed in other areas, where LULC occurred due to the tsunami impact or human activities like deforestation or urban growth. These results suggest that LULC changes should be taken into account in the framework of a hazard analysis. Remote sensing based classifications are therefore considered essential to provide a multi-temporal and spatial distribution of LULC and eventually bottom friction. Eventually, based on corrected digital elevation models and land cover roughness, detailed hazard maps could be produced for the study areas. 

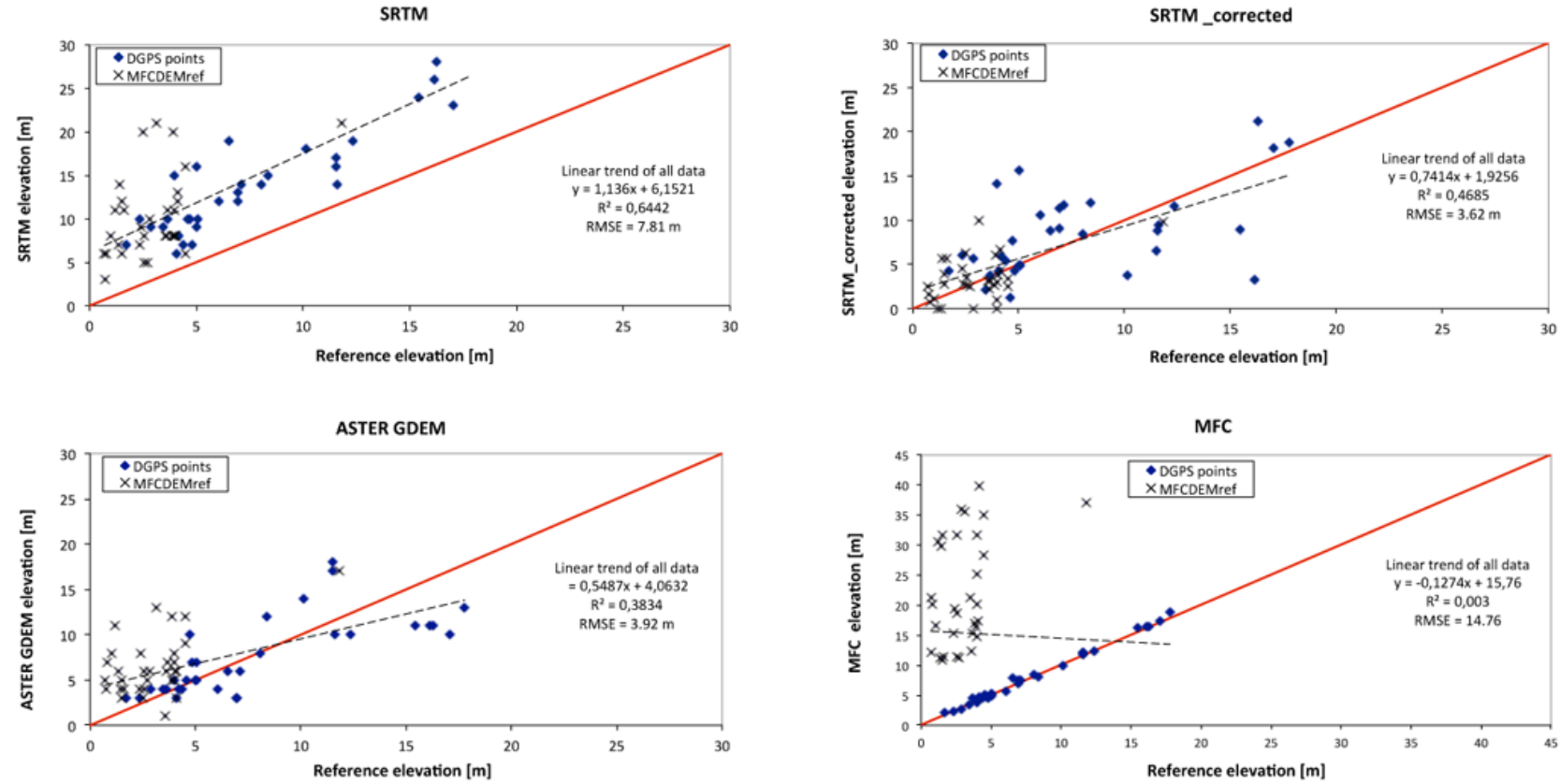

Fig. 7. Validation of SRTM, SRTM_corrected, ASTER GDEM, and MFC against measured DGPS and MFC DEM ref points.

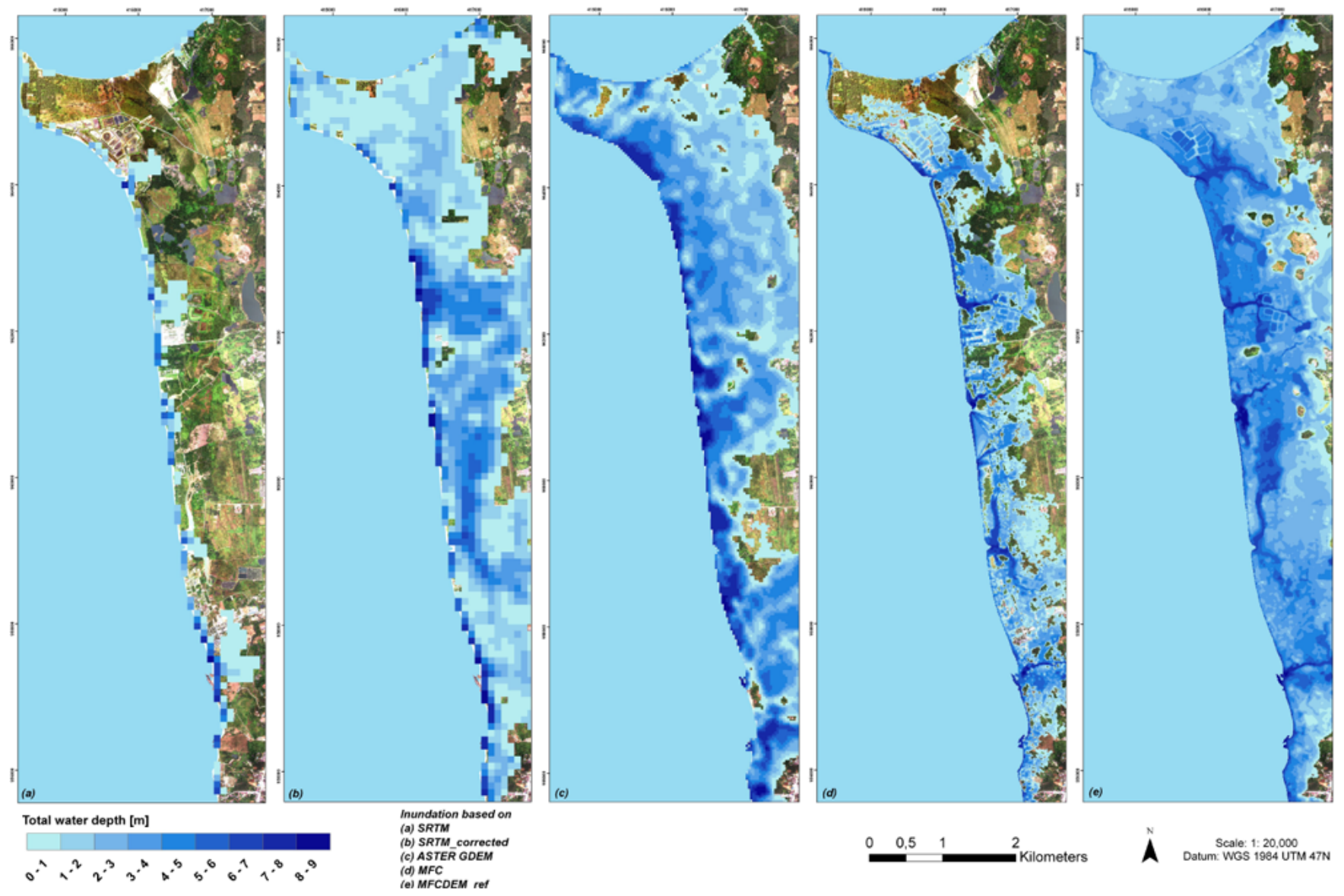

Fig. 8. Maximum total water depth for (a) SRTM, (b) SRTM_corrected, (c) ASTER GDEM, (d) MFC, and (e) MFC DEM ref . 


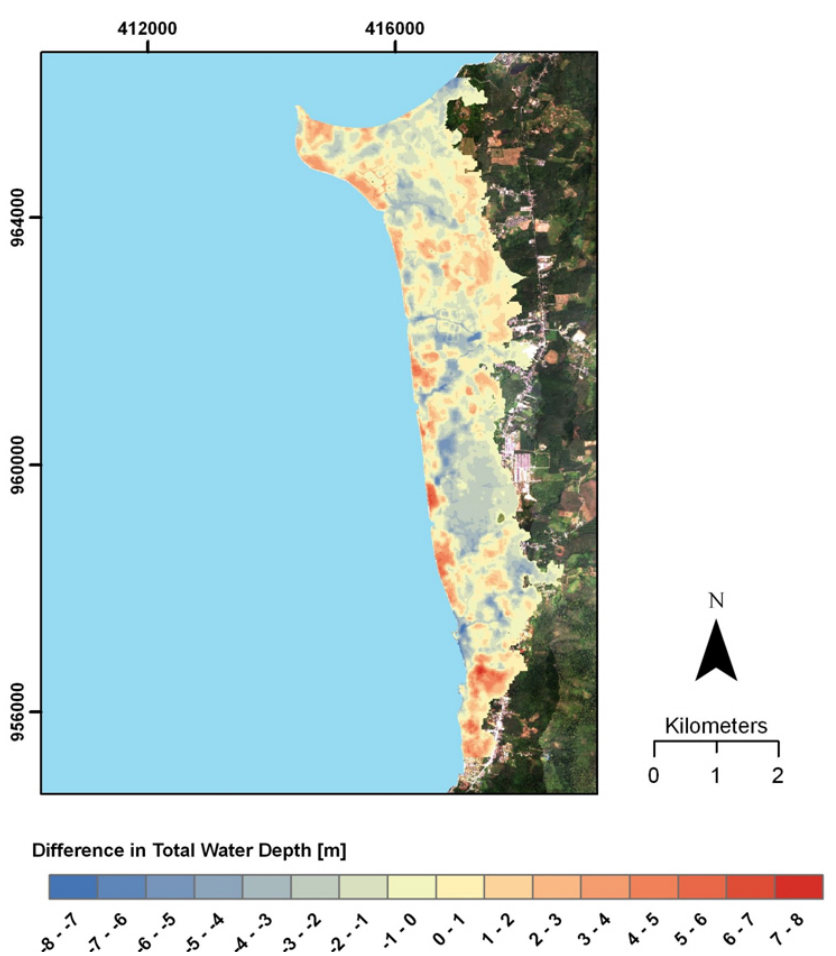

Fig. 9. Difference image between inundation simulations based on ASTER GDEM and MFC DEM ref.

\subsection{Socio-economic vulnerability analysis}

Basic indicators for economic vulnerability assessment are the exposed assets that consist of (a) the direct exposed elements, i.e. the amount of directly affected assets and (b) the economic elements that might trigger indirect effects in other economically connected regions (UNDP-BCPR, 2004; Smith and Ward, 1998; Cochrane, 2004).

The physical damage is limited to the tsunami inundation areas, but nevertheless the effects of the natural hazard spread out following the economic linkages, such as sales and supply connections or impact households by the reduction of wages and salaries. The region of Khao Lak will be discussed in detail here. The spatial setting of this region, with its high concentration of resorts along the coastline, influences the distribution of exposed assets. In case of devastation, high indirect effects will propagate to the connected households and companies and cause losses there as well.

Figure 10 illustrates the distribution of damages on object level, as derived from the structural equation model. The total accumulated damage for the households in the area reached nearly 7 million Euro. This includes damage to buildings and long-term consumable assets. This damage was calculated using the damage function from the structural equation model, the pre-tsunami assets and the location indicators for each household. Hotspots for physical damage can be observed in the agglomerations of hotel complexes in the
Table 6. Exposed assets in Khao Lak.

\begin{tabular}{lrr}
\hline Feature & Total & $\begin{array}{r}\text { Thereof located } \\
\text { in inundation zone }\end{array}$ \\
\hline Number of persons & 9741 & $37.0 \%$ \\
Amount of household assets in $€ 1000$ & 17800 & $37.0 \%$ \\
Amount of income per month in $€ 1000$ & 751 & $36.4 \%$ \\
Number of companies & 294 & $43.9 \%$ \\
Number of employees & 1405 & $40.2 \%$ \\
Amount of company assets in $€ 1000$ & 685960 & $91.9 \%$ \\
\hline
\end{tabular}

southern part of Khao Lak. In total, the damage to company property exceeded 90 million due to the high number of completely destroyed hotel complexes.

Significant impact on residential buildings could only be observed along the main road in the village of Bang Niang and near Pakarang Cape. It is obvious that the hotel business in the area dominated the total damage, with an average loss per square meter more than twice the amount of the residential buildings.

\subsection{Ecological vulnerability analysis}

Table 7 illustrates the results of the exposure, impact and recovery analysis. The results on tsunami impacts originated from the DMC, which emerged as the more efficient tool for damage assessments in comparison to the CVA. Regarding the recovery assessment, the combined approach of CVA turned out to be more useful for a qualitative assessment in comparison to the TNDVI-based approach and thus was considered in this table (Roemer et al., 2010; Römer et al., 2011). Figure 11 shows a map of the socio-economic and ecological exposure, exemplified for the Khao Lak area.

Mangrove forests were the least exposed ecosystem, which is mainly due to their occurrence in sheltered estuary areas in the south, which were largely protected from tsunami impacts. Field data revealed slow recovery processes indicated by low growth rates. Furthermore, changes in community structure with abundances of Casuarina equisetifolia indicate disturbed habitat conditions and a low adaptive potential to changing environmental conditions. Casuarina beach forests form narrow forest stands on beach ridges near the shore. These characteristics rendered them the most exposed and susceptible ecosystem. Furthermore, high damage values and a relatively small recovery area were observed. Low recovery values were partly the result of post-tsunami human activities that took place in the initial forest areas and second, a land-ward shift of vegetation due to coastal erosion. A high invasive potential of Casuarina equisetifolia, high growth rates and a high stability in species composition make casuarina beach forests very resilient. Observed impacts in coconut plantations were very likely overestimated due to man-made activities that took place between 13 January 2003 and the tsunami event. Field observations revealed that coconut trees were only directly impacted near the shoreline (less than 

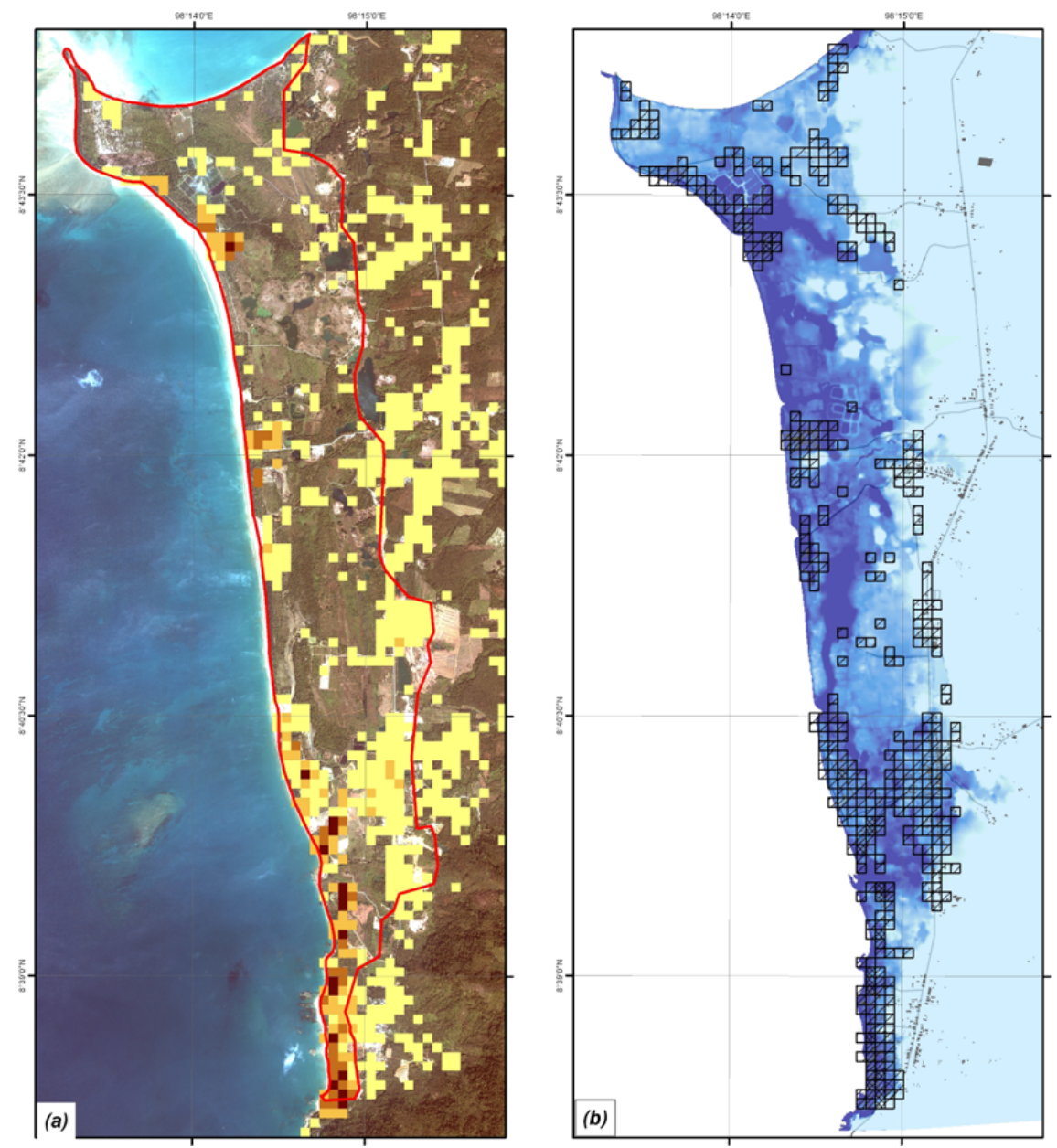

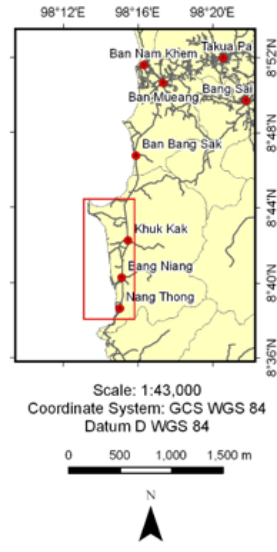

Legend

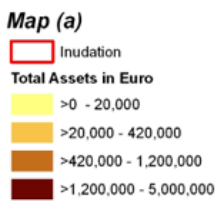

Map (b)

Damage in Euro

$Z>0-9,000$

QZ7 $>9,000 \cdot 31,500$

WII $>31,500-177,000$

$>177,000-4,000,000$

Inundation height (m)

8.4

4.2

Buildings

Fig. 10. Distribution of assets prior and damage after the tsunami 2004.
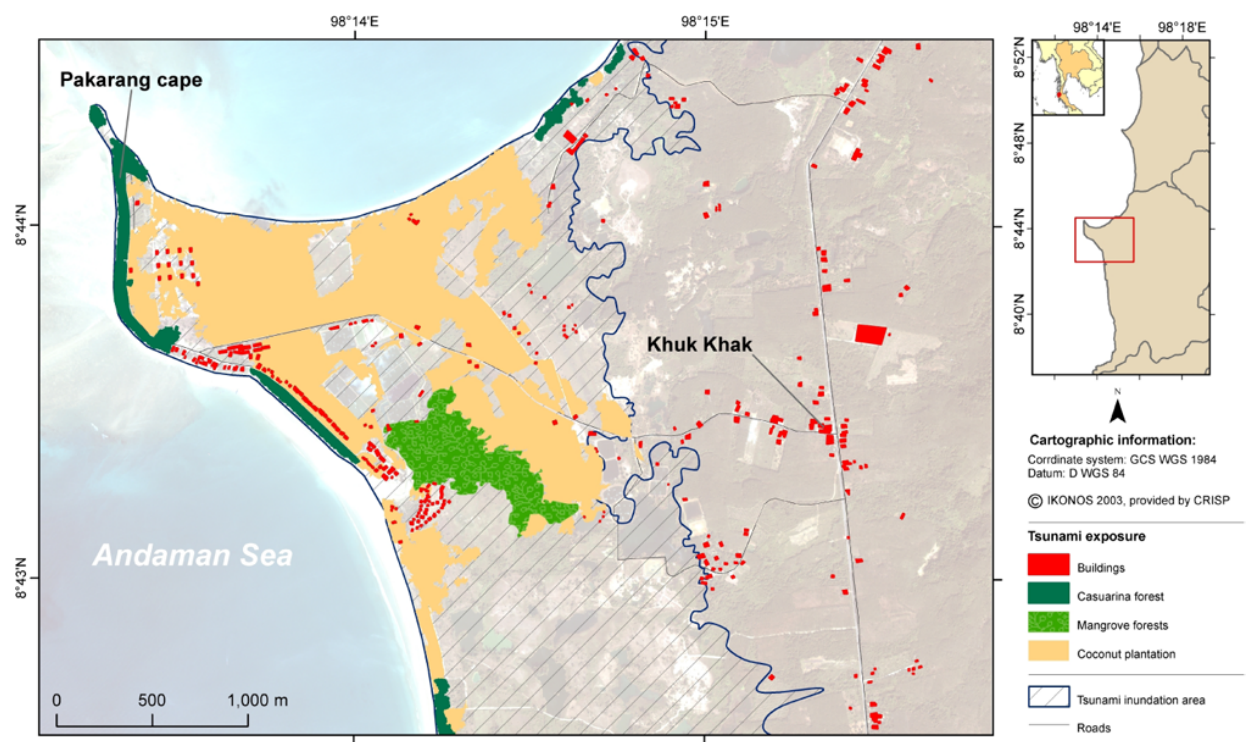

Fig. 11. Exposure map including socio-economic and ecological components. 
Table 7. Results of the analysis of ecological exposure, tsunami induced imapcts and recovery.

\begin{tabular}{|c|c|c|c|c|c|c|c|c|}
\hline \multirow[t]{2}{*}{ Coastal ecosystem } & \multicolumn{4}{|c|}{ Exposure information } & \multicolumn{2}{|c|}{ Direct impacts* } & \multicolumn{2}{|c|}{ Recovery } \\
\hline & Dominant tree species & $\begin{array}{l}\text { Total } \\
\text { area } \\
\text { (ha) }\end{array}$ & $\begin{array}{l}\text { Exposed } \\
\text { area } \\
(\mathrm{ha} / \%)\end{array}$ & $\begin{array}{l}\text { Average } \\
\text { shoreline } \\
\text { distance } \\
(\mathrm{m})\end{array}$ & $\begin{array}{l}\text { Total } \\
\text { area } \\
\text { (ha) }\end{array}$ & $\begin{array}{l}\% \text { of } \\
\text { exposed } \\
\text { area/\% of } \\
\text { total area }\end{array}$ & $\begin{array}{l}\% \text { of } \\
\text { impact } \\
\text { area* }\end{array}$ & $\begin{array}{l}\text { Recovery } \\
\text { rate** }\end{array}$ \\
\hline Mangrove forest & $\begin{array}{l}\text { Rhizophora apiculata, } \\
\text { R. mucronata, Ceriops } \\
\text { tagal, Avicennia sp., } \\
\text { Bruguiera gymnorrhiza }\end{array}$ & 980.17 & $111.12 / 11.33$ & 891 & 59.59 & $54.63 / 6.15$ & 56.2 & Slow \\
\hline $\begin{array}{l}\text { Casuarina beach } \\
\text { forest }\end{array}$ & $\begin{array}{lr}\text { Casuarina equisetifolia, } \\
\text { Pandanus } & \text { odoratis- } \\
\text { simus, } & \text { Barringtonia } \\
\text { asiatica } & \end{array}$ & 98.06 & $98.06 / 100.00$ & 75 & 37.24 & $37.98 / 37.98$ & 55.8 & Fast \\
\hline Coconut plantation & Cocos nucifera & 494 & $451.00 / 91.13$ & 391 & 124.61 & $27.63 / 25.22$ & 78.1 & None \\
\hline Melaleuca forests & $\begin{array}{l}\text { Melaleuca } \\
\text { leucadendron }\end{array}$ & 49.13 & $46.04 / 93.71$ & 343 & 0.56 & $1.22 / 1.14$ & $\mathrm{n} / \mathrm{a}$ & Fast \\
\hline $\begin{array}{l}\text { Mixed beach } \\
\text { forests }\end{array}$ & $\begin{array}{l}\text { Syzigium grande, Euge- } \\
\text { nia sp., Diospyros sp., } \\
\text { Shorea sp., Lepisanthes } \\
\text { rubigunosa }\end{array}$ & 193.05 & $137.32 / 71.13$ & 263 & 1.72 & $1.25 / 0.89$ & $\mathrm{n} / \mathrm{a}$ & Fast \\
\hline
\end{tabular}

* derived from CVA (Römer et al., 2011); ** estimated from both, CVA and field measurements conducted in 2009.

Table 8. Correlation coefficients calculated for the tsunami impacts and recovery potential

\begin{tabular}{|c|c|c|c|c|}
\hline \multirow[t]{2}{*}{ Independent variables } & \multicolumn{2}{|c|}{ Tsunami impacts $I(\%)$} & \multicolumn{2}{|c|}{ Recovery potential $R(\%)^{* *}$} \\
\hline & $\begin{array}{l}\text { Mangroves } \\
(N=10521)\end{array}$ & $\begin{array}{l}\text { Mixed } \\
\text { vegetation } \\
\text { cover } \\
(N=59838)\end{array}$ & $\begin{array}{l}\text { Mangroves } \\
(N=720)\end{array}$ & $\begin{array}{l}\text { Mixed } \\
\text { vegetation } \\
\text { cover } \\
(N=22425)\end{array}$ \\
\hline Maximum current speed, $S_{\mathrm{C}}\left(\mathrm{m} \mathrm{s}^{-1}\right)$ & $+0.55^{*}$ & $+0.54 *$ & N/A & N/A \\
\hline Maximum total water depth above ground, $D_{\mathrm{G}}(\mathrm{m})$ & $+0.35^{*}$ & $+0.48 *$ & N/A & N/A \\
\hline Distance to shoreline, $D_{\mathrm{S}}(\mathrm{m})$ & $-0.43 *$ & $-0.48 *$ & $-0.11 *$ & +0.01 \\
\hline Distance to river, $D_{\mathrm{R}}(\mathrm{m})$ & $-0.22 *$ & $-0.01 *$ & $+0.28 *$ & $+0.09 *$ \\
\hline Elevation above sea level, $E(\mathrm{~m})$ & $-0.11 *$ & $-0.50 *$ & $+0.48^{*}$ & $+0.27 *$ \\
\hline Disturbance variable, $A_{\mathrm{D}}(\%)$ & N/A & N/A & $-0.53 *$ & -0.01 \\
\hline Depth of topographic sinks, $S(\mathrm{~m})$ & $+0.18 *$ & $-0.05 *$ & $-0.19 *$ & $-0.03 *$ \\
\hline Inclination of coastline, $I\left({ }^{\circ}\right)$ & $+0.20 *$ & $+0.12 *$ & N/A & N/A \\
\hline Intensity of post-tsunami human activities, $H(\%)$ & N/A & N/A & $+0.14 *$ & $-0.27 *$ \\
\hline Pre-tsunami NDVI, NDVI & $-0.40 *$ & N/A & N/A & N/A \\
\hline
\end{tabular}

* correlation is significant at the 0.01 level (2-tailed); ** lower values of $N$ used for the recovery analysis are mainly due to missing IKONOS imagery for the Thai Mueang area for the year 2008 .

$100 \mathrm{~m}$ ), so that the actual impacted plantation area can be estimated with $5-10 \%$. Due to their artificial character, coconut plantations did not recover to their initial community structure. Tsunami impacts in melaleuca and mixed beach forests were relatively low and hardly any long-term tsunami effects could be noticed in the field (Chatenoux and Peduzzi, 2005, Duke, 2006; Römer et al., 2011; Whistler and Elevitch, 2006).

\subsubsection{Spatial patterns of tsunami impacts and recovery}

Table 8 and Fig. 12 show the results of the correlation analysis for the mangroves and mixed vegetation cover class, comprising all vegetated areas in the study area. Regarding the impacts in mangroves, the most important variables are $S_{\mathrm{C}}(r=0.55)$ and $D_{\mathrm{S}}(r=0.43)$. Lower coefficients occur for NDVI $(r=0.40), D_{\mathrm{G}}(r=0.35)$ and $D_{\mathrm{R}}$ $(r=0.22)$. The results for variables $D_{\mathrm{S}}$ and $D_{\mathrm{R}}$ confirm the 

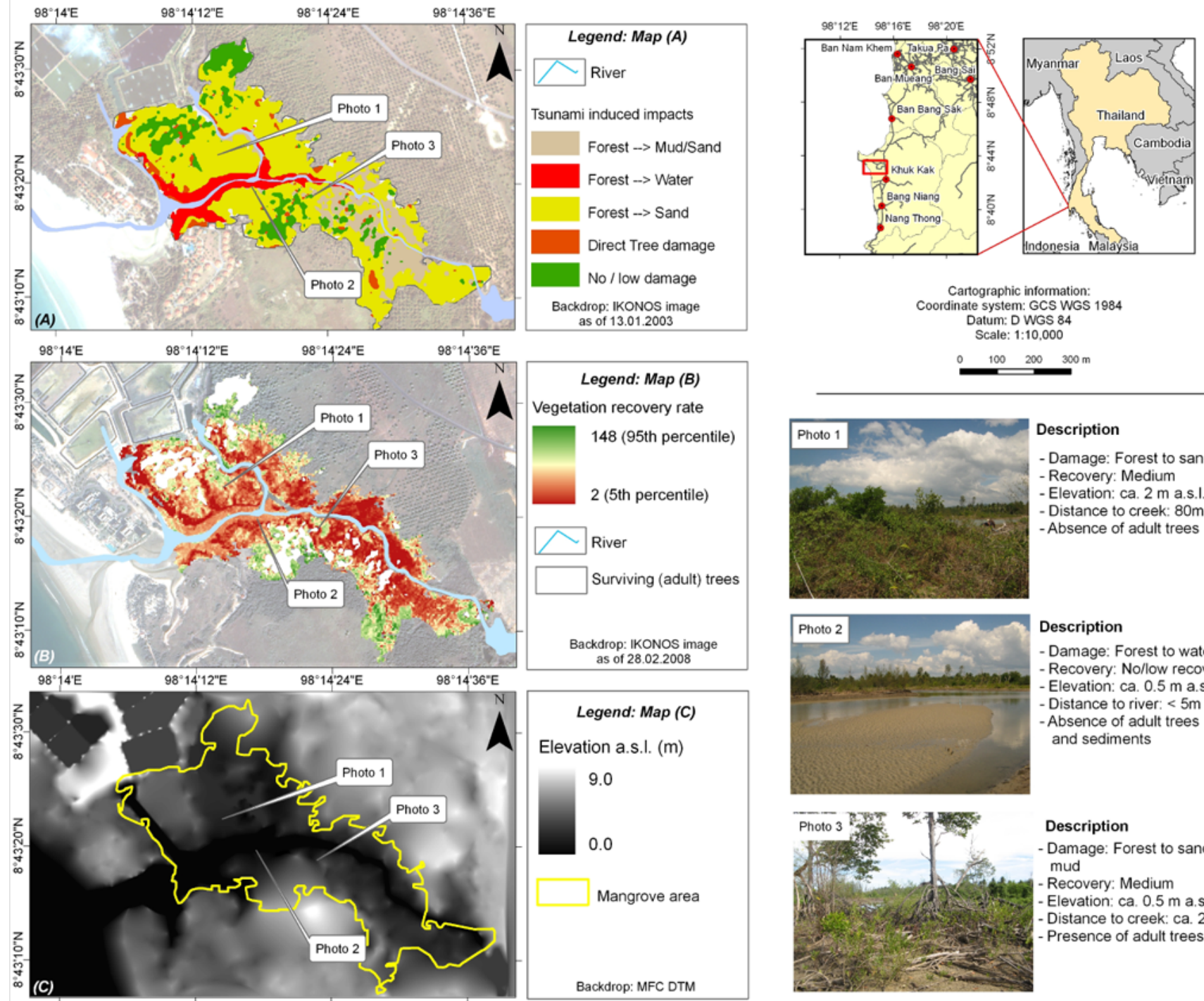

Description

- Damage: Forest to sand - Recovery: Medium - Elevation: ca. 2 m a.s.l. - Distance to creek: $80 \mathrm{~m}$ - Absence of adult trees

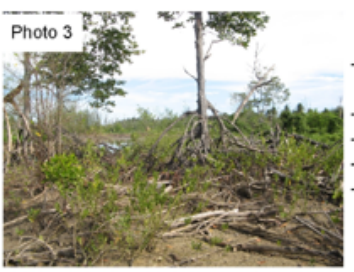

Description

- Damage: Forest to sand / mud

- Recovery: Medium

Elevation: ca. $0.5 \mathrm{~m}$ a.s. $\mathrm{L}$

Distance to creek: ca. $20 \mathrm{~m}$

- Presence of adult trees

Fig. 12. Impacts and recovery patterns for a mangrove stand near Cape Pakarang.

own field observations and those of Paphavasit et al. (2009) and Yanagisawa et al. (2009). A relatively high contribution of the pre-tsunami NDVI implies that impacts were likely more pronounced in low density forest areas, e.g. dwarf mangroves in the outer mangrove fringes. Regarding the mixed vegetation cover class, tsunami impacts were generally best correlated to $S_{\mathrm{C}}(r=0.54), E(r=0.50), D_{\mathrm{G}}(r=0.48)$ and $D_{\mathrm{S}}(r=-0.48)$.

Recovery potential in mangroves was mainly determined by $A_{\mathrm{D}}(r=-0.53)$ and $E(r=0.48)$ confirming the field observations of the author: particularly in the high impacted areas near the coast, creeks and in depressions, growth processes could only set in after the eroded sediments and organic matter had been restored. Furthermore, mangrove succession usually starts from the inner, less impacted and slightly more elevated areas with higher abundances of mature trees acting as growth points for forest renewal (Adger et al., 2005). Only low coefficients could be detected for the mixed vegetation cover class, implying that the determining factors for recovery processes differ much among the investigated ecosystems. As the coastal area is intensely influenced by human activities (e.g. tourist industry or aquaculture), it was assumed that these negatively affect ecosystem health and their recover potential. As it was described in Roemer et al. (2011), these effects need to be investigated for larger study areas, and their influence on vegetation recovery could not be clearly proved by the selected statistical approach.

Multiple regression models applied for the mangrove ecosystem (Table 9) reveal that tsunami impact and recovery patterns can be roughly predicted using location, exposure and disturbance variables. It is indicated that a substitution of 
Table 9. Results of the regression analysis represented for the mangrove ecosystem.

\begin{tabular}{|c|c|c|c|c|c|c|c|c|c|c|c|}
\hline \multirow[t]{2}{*}{ Corr. $R^{2}$} & \multirow{2}{*}{$\begin{array}{l}\text { Dependent } \\
\text { variable }\end{array}$} & \multirow[t]{2}{*}{ Variable group } & \multicolumn{9}{|c|}{ Independent variables (standardized beta values*) } \\
\hline & & & $D_{\mathrm{S}}$ & $D_{\mathrm{R}}$ & $E$ & $I$ & NDVI & $S_{\mathrm{C}}$ & $D_{\mathrm{G}}$ & $A_{\mathrm{D}}$ & $H$ \\
\hline 0.43 & Impact & Hazard, Exposure & $\mathrm{n} / \mathrm{a}$ & $\mathrm{n} / \mathrm{a}$ & $\mathrm{n} / \mathrm{a}$ & $\mathrm{n} / \mathrm{a}$ & $\mathrm{n} / \mathrm{a}$ & +0.40 & +0.16 & $\mathrm{n} / \mathrm{a}$ & $\mathrm{n} / \mathrm{a}$ \\
\hline 0.33 & Impact & Location, Exposure & -0.39 & -0.12 & -0.11 & +0.05 & -0.37 & $\mathrm{n} / \mathrm{a}$ & $\mathrm{n} / \mathrm{a}$ & $\mathrm{n} / \mathrm{a}$ & $\mathrm{n} / \mathrm{a}$ \\
\hline 0.50 & Recovery & Location, Disturbance & +0.08 & +0.09 & +0.37 & $\mathrm{n} / \mathrm{a}$ & $\mathrm{n} / \mathrm{a}$ & $\mathrm{n} / \mathrm{a}$ & $\mathrm{n} / \mathrm{a}$ & -0.50 & +0.18 \\
\hline
\end{tabular}

* Variance Inflation Factor (VIF) was considered in order to avoid multicollinearity among independent variables.

location variables by hazard variables led to clear improvement of the model quality. Further statistical results for the other ecosystems are described in Römer (2011).

\section{Discussion}

This paper highlighted the potential of applying remote sensing for tsunami hazard and vulnerability analysis. Referring to the major research challenges raised in section 1, this study provided substantial information on the value and accuracy of different remotely sensed data and methods to support hazard and vulnerability assessments on a local scale. Furthermore, the study led to some conclusions on the transferability and robustness of the conducted methodological approaches to be discussed in this section.

As an integrative finding it can be concluded that remotely sensed data and their derived products support the geo-spatial assessment of (a) tsunami hazard, in particular through the provision of input data required for inundation modeling and (b) tsunami vulnerability, through the possibility to regionalize and predict socio-economic in-situ data and to spatially investigate the exposure assets as well as the sensitivity and resilience of coastal ecosystems. In particular the basic geodata, including LULC, building polygons and DEMs served as a crucial data source in all of the three case studies on hazard and vulnerability assessment. However, despite using high resolution imagery, it can be concluded that an accurate assessment of vulnerability cannot be done with remote sensing techniques alone. Thus, a significant potential of remote sensing can be seen in providing added value through the combined use of Earth observation technology and other methodologies, such as field investigations and data collections, statistical approaches and inundation modeling.

\subsection{Hazard analysis}

Results of the hazard analysis show that remote sensing data and techniques are essential to provide input data necessary for a spatially explicit hazard analysis. The most important application of remote sensing in the hazard analysis is the generation of digital elevation models and of (multi-temporal) LULC maps, which can be transferred into roughness maps accounting for bottom roughness in a numerical tsunami inundation simulation.

Although DEMs based on remote sensing data come with some inaccuracies compared to DGPS measurements, they have the advantage of representing the spatial distribution of land elevation, even for larger regions. Since inundation of low-lying areas is normally in the order of magnitude of decimeters to few meters, a high accuracy of the topographic data used in a numerical model is necessary for simulating inundation and for deriving water levels accurate enough to estimate possible damages to e.g. buildings. Only the highresolution data (MFC data in this case) allow for this very detailed and accurate inundation modeling in our local study. Since the original data also included buildings in their height description, processes related to obstacles could also be analyzed. However, with respect to transferability and applicability, the use of these data is hampered by e.g. costs, the grid point restriction in numerical models, and the computational demands. If only the inundation extent is required and objectbased analysis of water depths and velocities (e.g. at buildings, in rivers or small terrain variations) is not the purpose of an analysis corrected SRTM or ASTER data would be suitable. However, the vegetation offset in remote sensing-based DSMs shows significant influence on the modeled inundation patterns, mainly leading to an underestimation of the inundation extent. The problem also occurs in urban areas (not shown in this paper), where dense settlement structures may lead to height offsets in the DSMs. Therefore, when applying e.g. SRTM data in inundation modeling, land cover offsets have to be considered and (if necessary) removed. Although this phenomenon is well known, SRTM data are widely used for inundation modeling in the absence of better data in many parts of the world and in regional and global studies. With detailed LULC information derived from remote sensing data, corrected DEMs can be generated, which could then improve modeling results. Although this methodology generated promising results for homogenous LULC classes, some restrictions became obvious: the vegetation heights to be subtracted are mean vegetation heights per LULC class. Also the height information in the SRTM raster cell is a function of the underlying earth's surface, which might vary within a cell and lead to inaccurate height information. It must also be noted that the LULC classification is based on 2003 imagery, 
while SRTM data were collected in 2000, when LULC may have been different.

Our study did not reveal a clear evaluation of the ASTER GDEM, since artifacts and height offsets could not be removed. The results from the inundation simulation based on the ASTER GDEM provided promising results for the inundation extent, but the results showed deviations of the local water depths compared to run-up measurements and compared to the simulation with the reference DEM. Further investigations need to be made in other study areas.

Inundation patterns may change when LULC changes, e.g. by a previous destructive flood event or human-made changes such as deforestation or urban growth. Remote sensing-based LULC classifications and change detection techniques based on optical images have proven to be useful tools to gain information on the spatial distribution of LULC and its temporal variations.

\subsection{Socio-economic vulnerability}

For the extrapolation and assessment of socio-economic vulnerability indicators, the application of remote sensing data offers large potential in terms of improving the accuracy and extending the spatial coverage. In this paper a regressionbased approach was developed, which builds up on remote sensing data combined with information collected during a field survey. The advantage of combining these two data sources lies in the possibility of achieving an exposure and damage analysis for every object in the surveyed area. Without integrating remotely sensed data, the representativeness of the survey would have been limited to the community scale. Therefore, the survey was designed in order to meet two requirements: (a) to be representative for the community level and (b) to allow the application of remote techniques. The latter was realized by considering geo-features, observable by means of remote sensing, such as building types and roof characteristics (Willroth, 2012).

Furthermore, it can be demonstrated that the accuracy of these methods can be significantly increased using a regression-based approach at building level compared to a dasymetric mapping method supported by secondary statistics. The comparison between the approach used in this paper and the dasymetric mapping carried out by Tiffert (2010) shows an agreement in population numbers with a difference of less than $10 \%$. This can be explained by the use of official statistics in the dasymetric mapping. However, spatial accuracy differs significantly among the two approaches, due to the assignment of population density figures to LU classes, which include the study area of Ban Nam Khem $0.8 \mathrm{~km}^{2}$ with around 180 buildings. Here the regression-based approach can show the major advantage of assigning the population accurately to each of the single houses.

Therefore, the costs of small-scale surveys can be acceptable in order to improve exposure and damage assessments. The extraction of indicators from remote sensing and survey data allows the development of shorter questionnaires and therefore the reduction of time and costs. Combining the regression-based approach with a hazard simulation allows a prediction of the damage. The use of regression-based analysis allows an application of the method for various types of houses and is therefore an improvement compared to applying mean values for households (Niebergall et al., 2008; Taubenböck et al., 2009).

On the other hand the limitations of this method are given by the underlying regression equations that might produce an over- or underestimation for the exposed assets and population as well as for the amount of damage, due to unexplained variance of the models. Furthermore, the approach depends on accurate data input from both survey and remote sensing data. The lack of precision in only one data source can strongly affect the results, since the models build on each other. Furthermore, the model relies only on indicators that are accessible using remote sensing, such as building characteristics. As a consequence the $R^{2}$ of the models shows a relatively low fit. Despite that, the models provide a valuable contribution towards a damage function, relying on remote sensing databases with minimal input from ground surveys. This could help to create damage functions tailored for the specific setting in the area that should be surveyed (Smith, 1994).

\subsection{Ecological vulnerability}

Ecological vulnerability was investigated based on a retrospective approach by combining object-oriented image classification, change detection and field investigations. The results served as a basis to investigate the main determining factors of the observed impacts and recovery patterns. Regarding the aspect of transferability, the combination of object oriented image classification and change detection turned out as an effective method combination: The classification results were not only useful for regionalizing exposure assets, but also for supplying the change detection application with accurate pre-disaster information and for performing a zone-based change detection. In contrast to the postclassification comparison, which can provide a full matrix of LULC changes, only one classification step was conducted in this study. This aspect makes this approach particularly transferrable (Lu et al., 2006).

From the statistical approach it can be concluded that remote sensing techniques can be used for a preliminary spatial assessment and prediction of vulnerable areas. Similar to the change detection approach, a crucial element is the availability of a reliable and accurate spatial data set on coastal ecosystems or LULC. The high spatial resolution of IKONOS imagery was necessary to extract the small patches of casuarina forests or the high textured coconut plantations. Nevertheless, a minimum of field data is a premise for creating accurate LULC information. If accurate LULC data were available, geo-features derived from remotely sensed data 
(e.g. elevation, rivers, coast line, LC changes) could be used to identify vulnerable areas in advance of a tsunami disaster (Nassel et al., 2006; Villa and McLeod, 2002). This makes this approach interesting and useful for other tsunami-prone areas, particularly those that are difficult to access and where accurate geo-data are rarely available. However, any predictions of vulnerability must be ecosystem-specific.

The statistical approach revealed that vulnerability is partly determined by extrinsic variables, as represented by location and disturbance variables. However, a comprehensive understanding and assessment of vulnerability requires also a good knowledge on the intrinsic vulnerability components, such as ecosystem health, functioning and resilience. These components require comprehensive ecological studies, comprising field work or laboratory analyses for longer time periods. However, a potential of applying remote sensing to assessing intrinsic (system-specific) vulnerability components can be seen as regarding the analysis of tsunami sensitivity: information on the pre-tsunami vegetation structure, such as stand density, stem thickness and age composition are important measures of forest susceptibility (Tanaka et al., 2007). These data can be collected on a sample basis in advance of a tsunami event and related and regionalized with the help of remotely sensed data. Due to the start of this study in 2008, this issue could not be further investigated. Promising approaches for a spatial estimation and quantification of tree and stand characteristics using optical and LIDAR data are described in Forzieri et al. (2012), Freitas et al. (2005) and Smith et al. (2004).

The synergy between in-situ data collection and remote sensing became also evident regarding the retrospective analysis of recovery patterns: Without in-situ data, recovery information observed from satellite imagery could not have been fully understood, e.g. in terms of changes in community structure or colonization processes. In contrast, without change detection, the area of recovery and the spatial patterns (e.g. the land-ward shift of casuarina beach forests) would remain unknown.

Further potential of remote sensing can be seen in the possibility to link the spatial data on exposure, impact and recovery to other information on ecological vulnerability derived from other sources. In this context, a detailed database on the state and temporal changes of ecosystem services and functions for major LULC classes was created for the study area in 2010 based on expert interviews. This information can be regionalized with the exposure and LULC map and also with the damage and recovery information provided by change detection. This synergistic approach would allow the estimation of regional losses and gains in ecosystem services as well as the social components of ecological vulnerability (Adger et al., 2005).

\section{Conclusions}

This study has provided a detailed overview of the extent to which remote sensing can support tsunami hazard and vulnerability analysis. Following an inductive approach applied for a small case study area, a comprehensive framework was adopted comprising the analysis of hazard and the social, economic and ecological aspects of vulnerability. The underlying idea was to use the 2004 tsunami event, for developing an in-depth understanding of the spatial characteristics of tsunami hazard and vulnerability and to gain practical knowledge on the benefits of using Earth observation data and derived products. The study confirms to some extent the findings of Taubenböck et al. (2008), providing a broad overview on the risk indicators that can be observed by means of remote sensing. In addition, it has provided a more in-depth understanding on the application of Earth observation data for certain aspects in tsunami hazard and vulnerability analysis. Potentials of this study might be seen in

- the adoption of a comprehensive vulnerability framework, where social, economic and ecological aspects of vulnerability were considered to an equal degree,

- the comprehensive evaluation and cross-comparison of different DEMs in context of tsunami hazard analysis and

- the availability of a sufficient amount of in-situ data (e.g. DGPS points, geo-coded photos, field survey data on socio-economic key features of vulnerability, field measurements on ecosystem recovery), providing a reliable source to evaluate remote sensing techniques in terms of accuracy or in applying them for synergistic purposes.

It can be concluded that LULC data, building polygons and DTMs as derived from DSMs turned out to be effective tools, which significantly improved the accuracy of a spatial investigation of tsunami hazard and tsunami exposure. Regarding the socio-economic vulnerability, several socioeconomic indicators, such as the education level or income diversification and other socio-economic assets influencing the resilience perspective of households and companies are not yet derivable from Earth observation data and still require the collection of survey data. It was also demonstrated that multi-temporal image analyses allow for a retrospective analysis of ecological vulnerability. Tsunami-induced impacts on ecosystems, which were used as an indicator to assess tsunami sensitivity, can be partially explained by locational factors (e.g. distance the shoreline, elevation a.s.l.). Additionally, the change detection results can be used to predict ecosystem recovery. However, a future challenge in this context will be the identification of robust measures or indicators for ecological resilience by means of remote sensing. 
Acknowledgements. We would like to acknowledge and thank the WWF-Team in Thailand and the Chulalongkorn University Social Research Institute for their support and assistance during the Field campaigns. The research presented in this article builds upon the project Tsunami Risks, Vulnerability and Resilience in the Phang-Nga Province, Thailand funded by the German Research Foundation. The project had a partner project funded by the National Research Council of Thailand.

Edited by: K. Schwarzer

Reviewed by: A. Muhari and another anonymous referee

\section{References}

Adger, W. N., Hughes, T. P., Folke, C., Carpenter, S. R., and Rockstrom, J.: Social-Ecological Resilience to Coastal Disasters, Science, 309, 1036-1039, doi:10.1126/science.1112122, 2005.

ASTER GDEM Validation Team: ASTER Global DEM Validation Summary Report, available at: https://lpdaac.usgs.gov/ (last access: November 2011), 2009.

Bahugana, A., Nayak, S., and Dam, R.: Impact of the tsunami and earthquake of 26th December 2004 on the vital coastal ecosystems of the Andaman and Nicobar Islands assessed using RESOURCESAT AWiFS data, Int. J. Appl. Earth. Obs., 10, 229237, 2008.

Basher, R.: Global early warning systems for natural hazards: systematic and people-centred, Philos. T. Roy. Soc. A, 364, 21672182, 2006.

Bates, P. D.: Remote sensing and flood inundation modeling, Hydrol. Process., 18, 2593-2597, 2004.

Bell, R., Cowan, H., Dalziell, E., Evans, N., O’Learly, M., Rush, B., and Yule, L.: Survey of impacts on the Andaman Coast, Southern Thailand following the great Sumatra-Andaman earthquake and tsunami of December 26, 2004, Bulletin of the New Zealand Society for Earthquake Engineering, 38, 123-148, 2004.

Birkmann, J. and Wisner, B.: Measuring the un-measurable - The challenge of vulnerability, SOURCE. No. 5/2006, Bonn, Germany, 64 pp., 2006.

Center for Satellite Based Crisis Information (ZKI): Overview satellite map (from archived imagery) of the Khao Lak region/Thailand, Wessling, Germany, available at: http://www.zki. dlr.de/map/770(last access: 4 December 2011), 2005.

Chang, S. E., Eeri, M., Adams, B. J., Alder, J., Berke, P. R., Chuenpagdee, R., Ghosh, S., and Wabnitz, C.: Coastal ecosystems and Tsunami protection after the December 2004 Indian Ocean Tsunami, Earthquake Spectra, 22, 863-887, 2006.

Chatenoux, B. and Peduzzi, P.: Analysis on the role of bathymetry and other environmental parameters in the impacts from the 2004 Indian Ocean Tsunami, A Scientific Report for the UNEP Asian Tsunami Disaster Task Force, UNEP/GRID-Europe, available at: http://www.grid.unep.ch/product/publication/ download/environment_impacts_tsunami.pdf (last access: 1 November 2011), 2005.

Chatenoux, B. and Peduzzi, P.: Impacts from the 2004 Indian Ocean Tsunami: analysing the potential protecting role of environmental features, Nat. Hazards, 40, 289-304, 2007.

Choowong, M., Phantuwongraj, S., Charoentitirat, T., Chutakosikanon, V., Yumuang, S., and Charusiri, P.: Beach recovery after 2004 Indian Ocean tsunami from Phang-nga, Thailand, Geomorphology, 104, 134-142, 2009.

Clark, W., Jaeger, J., Corell, R., Kasperson, R., McCarthy, J., Cash, D., Cohen, S., Desanker, P., Dickson, N., Epstein, P., Guston, D., Hall, J., Jaeger, C., Janetos, A., Leary, N., and Levy, M.: Assessing Vulnerability to Global Environmental Risks, Cambridge, Discussion paper, 2000-12, 2000.

Cochrane, H.: Economic Loss: Myth and Measurement, Disaster Prevention and Management, 13, 290-296, 2004.

Coveney, S., Fotheringham, A. S., Charlton, M., and McCarthy, T.: Dual-scale validation of a medium-resolution coastal DEM with terrestrial LiDAR DSM and GPS, Comput. Geosci., 36, 489-499, 2010.

Dahdouh-Guebas, F.: Mangrove Vegetation Structure Dynamics and Regeneration, Dissertation, Vrije Universiteit Brussel, Brussels, Belgium, 317 pp., 2001.

Department of Marine and Coastal Resources (DMCR): Rapid Assessment of the Tsunami Impact on Marine Resources in the Andaman Sea, Bangkok, Thailand, p. 76 pp., 2005.

DHI: MIKE 21 \& MIKE 3 FLOW MODEL FM, Hydrodynamic and Transport Module, Scientific Documentation, 2009.

Dray, S.: A New Perspective about Moran's Coefficient: Spatial Autocorrelation as a Linear Regression Problem, Geogr. Anal., 43, 127-141, doi:10.1111/j.1538-4632.2011.00811.x, 2011.

Duke, N. C.: Rhizophora apiculata, R. mucronata, R. stylosa, R. annamalai, R. - lamarckii (Indo-West Pacific stilt mangroves), ver. 2.1., in: Species Profiles for Pacific Island Agroforestry, Permanent Agriculture Resources (PAR), edited by: Elevitch, C. R., Hlualoa, Hawai, available at: http://www.traditionaltree.org (last access: 25 September 2011), 2006.

Eichenberg-Suvarnatisha, D.: Dezimierung und Deteriorierung natürlicher Ressourcen in Thailand unter besonderer Berücksichtigung der Entwaldung und von Gegensteuerungsmaßnahmen insbesondere mittels Schutzflächenausweisung, Dissertation, Johann-Wolfgang-Goethe-Universitat zu Frankfurt am Main, Frankfurt, Germany, 727 pp., 1991.

Falorni, G., Teles, V., Vivoni, E. R., and Bras, R. L.: Analysis and characterization of the vertical accuracy of digital elevation models from the Shuttle Radar Topography Mission, J. Geophys. Res., 110, F02005, doi:10.1029/2003JF000113, 2005.

Forzieri, G., Castelli, F., and Preti, F.: Advances in remote sensing of hydraulic roughness, Int. J. Remote Sens., 33, 630-654, 2012.

Freitas, S. R., Mello, M. C. S., and Cruz, C. B. M.: Relationships between forest structure and vegetation indices in Atlantic Rainforest, Forest Ecol. Manag., 218, 353-362, 2005.

Fujioka, Y., Tabuchi, R., Hirata, Y., Yoneda, R., Patanaponpaiboon, P., Poungparn, S., Shibuno, T., and Ohba, H.: Disturbance and recovery of mangrove forests and macrobenthic communities in Andaman Sea Thailand following the Indian Ocean Tsunami, Proceedings of the 11th International Coral Reef Symposium, 7-11 July 2008, Ft. Lauderdale, Florida, 825-829, 2008.

Gallant, J. and Hutchinson, M. F.: Producing digital elevation models with uncertainty estimates using a multi-scale Kalman filter, Proc. 7th International Symposium on Spatial Accuracy Assessment in Natural Resources and Environmental Sciences, 2006.

Gayer, G., Leschka, S., Nöhren, I., Larsen, O., and Günther, H.: Tsunami inundation modelling based on detailed roughness maps of densely populated areas, Nat. Hazards Earth Syst. Sci., 10, 1679-1687, doi:10.5194/nhess-10-1679-2010, 2010. 
Gesch, D. B.: Analysis of Lidar Elevation Data for Improved Identification and Delineation if Lands Vulnerable to Sea-Level Rise, J. Coast. Res., 53, 49-58, 2009.

ESPON (European Spatial Planning Observation Network: Glossary of Terms, available at: http://www.gsf.fi/projects/espon/ glossary.htm (last access: 14 June 2010), 2003.

Gorokhovich, Y. and Voustianiouk, A.: Accuracy assessment of the processes SRTM-based by CGIAR using field data from USA and Thailand and its relation to terrain characteristics, Remote Sens. Environ., 104, 409-415, 2006.

Goseberg, N. and Schlurmann, T.: Relevant factors on the extent of inundation based on tsunami scenarios for the city of Padang, West Sumatra, in: Proc. International Conference on Tsunami Warning (ICTW) Bali, Indonesia, 12-14 November, 2008.

Green, N.: Aerial Photographic Analysis of Residential Neighborhoods: An Evaluation of Data Accuracy, Social Forces, 35, 142$147,1956$.

Haase, D. and Frotscher, K.: Topography data harmonisation and uncertainties applying SRTM, laser scanner and cartographic elevation models, Adv. Geosci., 5, 65-73, doi:10.5194/adgeo-5-652005, 2005.

Hirt, C., Filmer, M. S., and Featherstone, W. E.: Comparison and validation of the recent freely available ASTER-GDEM ver1, SRTM ver4.1 and GEODATA DEM-9S ver3 digital elevation models over Australia, Aust. J. Earth Sci., 57, 337-347, 2010.

Hofton, M., Dubayah, R., Blair, J. B., and Rabine, D.: Validation of SRTM Elevations over Vegetated and Non-vegetated Terrain Using Medium Footprint Lidar, Photogramm. Eng. Rem. S., 73, 279-285, 2006.

Horne, J. H.: A tasseled cap transformation for IKONOS images, Proceedings of the ASPRS Annual Conference, 5-9 May 2003, Anchorage, USA, 9 pp., 2003.

Ioualalen, M., Asavanant, J., Kaewbanjak, N., Grilli, S. T., Kirby, J. T., and Watts, P.: Modelling the 26 December 2004 Indian Ocean tsunami: Case study of impact in Thailand, J. Geophys. Res., 112, C07024, doi:10.1029/2006JC003850, 2007.

Jakeman, J. D., Nielsen, O. M., van Putten, K., Mleczko, R., Burbridge, D., and Horspool, N.: Towards spatially distributed quantitative assessment of tsunami inundation models, Ocean Dynam., 60, 1115-1138, doi:10.1007/s10236-010-0312-4, 2010.

Johnson, R. D.: Change Vector Analysis for disaster assessment: a case study of Hurricane Andrew, Geocarto International, 9, 4115, 1994.

Jones, K. B., Heggem, D. T., Wade, T. G., Neale, A. C., Ebert, D. W., Nash, M. S., Mehaffey, M. H., Hermann, K. A., Selle, A. R., and Augustine, S.: Indicator Development for Landscape- Level Aquatic Ecological Vulnerability Assessment in Western United States (Poster), US Environmental Protection Agency (EPA), 2003.

Kaiser, G., Scheele, L., Kortenhaus, A., Løvholt, F., Römer, H., and Leschka, S.: The influence of land cover roughness on the results of high resolution tsunami inundation modeling, Nat. Hazards Earth Syst. Sci., 11, 2521-2540, doi:10.5194/nhess-112521-2011, 2011.

Kamthonkiat, D., Rodfai, C., Saiwanrungkul, A., Koshimura, S., and Matsuoka, M.: Geoinformatics in mangrove monitoring: damage and recovery after the 2004 Indian Ocean tsunami in Phang Nga, Thailand, Nat. Hazards Earth Syst. Sci., 11, 18511862, doi:10.5194/nhess-11-1851-2011, 2011.
Kongko, W., Leschka, S., Larsen, O., Gayer, G., Nöhren, I., and Günther, H.: A sensitivity test of tsunami modelling using various data: case study in Cilacap Indonesia, in: Proc of the International Conference on Tsunami Warning (ICTW), Bali, Indonesia, 12-14 November, 2008.

Kumpulainen, S.: Vulnerability concepts in hazard and risk management, in: Natural and technological hazards and risk affecting the spatial development of Europe regions, edited by: SchmidtThom, P., Geological Survey of Finland, Special Paper 42, Espoo, Finland, 65-74, 2006.

Laben, C. A. and Brower, B. V.: Process for enhancing the spatial resolution of multispectral imagery using pan-sharpening, Eastman Kodak Company, Technical Report US Patent \#6.011.875, 2000.

Li, A., Wang, A., Liang, S., and Zhou, W.: Eco-environmental vulnerability evaluation in mountainous region using remote sensing and GISA case study in the upper reaches of Minjiang River, China, Ecol. Model., 192, 175-187, 2006.

Li, J. and Wong, D. W. S.: Effects of DEM sources on hydrologic applications. Computers, Environment and Urban Systems 34, 251-261, 2010

Liu, X., Sakai, S., Mikami, T., Iwama, S., Imamura, F., Shuto, N., and Kikuchi, H.: Numerical analysis on tsunami run-up and tsunami flood to a coastal city, in: Proceedings of the 28th International Conference Coastal Engineering 2002, Solving Coastal Conundrums, 1, Cardiff, Wales, 116-1175, 2002.

Lohmann, P. and Jacobsen, K.: Filterung segmentierter Oberflächenmodelle aus Laserscandaten, PFG, 4, 279-287, 2004.

Løvholt, F., Bungum, H., Harbitz, C. B., Glimsdal, S., Lindholm, C. D., and Pedersen, G.: Earthquake related tsunami hazard along the western coast of Thailand, Nat. Hazards Earth Syst. Sci., 6, 979-997, doi:10.5194/nhess-6-979-2006, 2006.

Lu, D., Mausel, P., Bronidizio, E., and Moran, E.: Relationships between forest stand parameters and Landsat TM spectral responses in the Brazilian Amazon Basin, Forest Ecol. Manag., 198, 149-167, 2004.

Ludwig, R. and Schneider, P.: Validation of digital elevation models from SRTM X-SAR for applications in hydrologic modeling, Journal of Photogrammetry \& Remote Sensing, 60, 339-358, 2006.

Mård Karlsson, J. and Arnberg, W.: Quality analysis of SRTM and HYDRO1K: a case study of flood inundation in Mozambique, Int. J. Remote Sens., 32, 267-285, doi:10.1080/01431160903464112, 2011.

Mas, J.-F.: Monitoring land cover changes: a comparison of change detection techniques, Int. J. Remote Sens., 20, 139-152, 1999.

McAdoo, B. G., Richardson, N., and Borrero, J.: Inundation distances and run-up measurements from ASTER, QuickBird and SRTM data, Aceh coast, Indonesia, Int. J. Remote Sens., 28, 2961-2975, 2007.

Millennium Ecosystem Assessment (MEA): Current State \& Trends, Capter 19 Coastal Systems, World Resources Institute, Washington, DC, 2005.

Monmonier, M. and Schnell, G.: Land-Use and Land-Cover Data and the Mapping of Population Density, The International Yearbook of Cartography, 24, 115-121, 1984.

Nassel, M. and Voigt, S.: Vulnerability Assessment of the Built Environment, in: Rapid and multidimensional vulnerability Assess- 
ment Sri Lanka, edited by: Birkmann, J., Fernando, N., Hettige, S., Amarasinghe, S., Jayasingam, T., Paranagama, D., Nandana, M. D. A., Nassel, M., Voigt, S., Grote, U., Engel, S., Schraven, B., and Wolferts, J., UNU-EHS, Colombo, Bonn, 10-22, 2006.

Niebergall, S., Loew, A., and Mauser, W.: Integrative Assessment of Informal Settlements Using VHR Remote Sensing Data - The Delhi Case Study, IEEE J. Sel. Top. Appl. Earth Observations Remote Sensing, 1, 193-205, doi:10.1109/JSTARS.2008.2007513, 2008.

Oliver-Smith, A.: Anthropological research on hazards and disasters, Annu. Rev. Anthropol., 25, 303-328, 1996.

Olwig, M. F., Sorensen, M. K., Rasmussen, M. S., Danielsen, F., Selvam, V., Hansen, L. B., Nyborg, L., Vestergaard, K. B., Parish, F., and Karunagaran, V. M: Using remote sensing to assess the protective role of coastal woody vegetation against tsunami waves, Int. J. Remote Sens., 28, 3153-3169, 2007.

Pajimans, K.: Part II Vegetation, in: New Guinea Vegetation, edited by: Pajimans K., van Balgooy, M .M. J., and Powell, J. M., CRISPO, Canberra, Australia, 81 pp., 1976.

Paphavasit, N., Aksornkoae, S., and De Silvia, J.: Tsunami Impact on Mangrove Ecosystem, Thailand Environmental Institute, Nonthaburi, Thailand, 211 pp., 2009.

Pimm, S. L.: The Balance of Nature?, Chicago, Univ. Chicago Press, 434 pp., 1991.

Plathong, J. and Sitthirach, N.: Traditional and current uses of mangrove forests in Southern Thailand. Wetland International: Thailand Programme/PSU, Publication No. 3, Hat Yai, Thailand, 91 pp., 1997.

Post, J., Mück, M., Zosseder, K., Steinmetz, T., Riedlinger, T., Strunz, G., Mehl, H., Dech, S., Birkmann, J., Gebert, N., Anwar, H. Z., and Harjono, H.: Tsunami risk assessment for local communities in Indonesia to provide information for early warning and disaster management, International Conference on Tsunami Warning (ICTW), Bali, Indonesia, 12-14 November 2008, 7 pp., 2008.

Reese, S.: Die Vulnerabilität des schleswig-holsteinischen Küstenraumes durch Sturmfluten - Fallstudien von der Nordund Ostseeküste, Berichte aus dem Forschungs- und Technologiezentrum Westküste der Universität Kiel, 30, Forschungs- und Technologiezentrum Westküste, 2003.

Rodriguez, E., Morris, C. S., and Belz, J. E.: A global assessment of the SRTM performance, Photogramm. Eng. Rem. S., 72, 249260, 2006.

Römer, H.: Assessment of tsunami vulnerability and resilience of coastal ecosystems at the Andaman Sea coast of Thailand - potential and limitations of remote sensing and GIS techniques for a local scale approach, $\mathrm{PhD}$ Thesis, Christian-AlbrechtsUniversität zu Kiel, Kiel, Germany, 186 pp., 2011.

Roemer, H., Kaiser, G., Sterr, H., and Ludwig, R.: Using remote sensing to assess tsunami-induced impacts on coastal forest ecosystems at the Andaman Sea coast of Thailand, Nat. Hazards Earth Syst. Sci., 10, 729-745, doi:10.5194/nhess-10-729-2010, 2010.

Römer, H., Jeewarongkakul, J., Kaiser, G., Ludwig, R., and Sterr, H.: Monitoring post-tsunami vegetation recovery in Phang-Nga province, Thailand, based on IKONOS imagery and field investigations - a contribution to the analysis of tsunami vulnerability of coastal ecosystems, Int. J. Remote. Sens., 0, 1-32, 2011.
Ruangrassamee, A., Yanagisawa, H., Foytong, P., Lukkunaprasit, P., Koshimura, S., and Imamura, F.: Investigation of TsunamiInduced Damage and Fragility of Buildings in Thailand after the December 2004 Indian Ocean Tsunami, Earthq. Spectra, 22, 377-401, 2006.

Sanders, B. F.: Evaluation of on-line DEMs for flood inundation modeling, Adv. Water Resour., 30, 1831-1843, 2007.

Schlurmann, T., Kongko, W., Goseberg, N., Natawidjaja, D. H., and Sieh. K.: Near-Field Tsunami Hazard Map Padang, West Sumatra: Utilizing High Resolution Geospatial Data and Reasonable Source Scenarios, in: Proceedings of the International Conference on Coastal Engineering, 1(32), available at: http: //journals.tdl.org/ICCE/article/view/1100, 2011.

Sirikulchayanon, P., Sun, W., and Oyana, T. J.: Assessing the impact of the 2004 tsunami on mangroves using remote sensing and GIS techniques, Int. J. Remote Sens., 29, 3553-3576, 2008.

Smith, D: Flood damage estimation - A review of urban stagedamage curves and loss functions, Water SA, 20, 231-238, 1994.

Smith, K. and Ward, R.: Floods: Physical processes and human impacts, Wiley, Chichester, 1998.

Smith, M. J., Asal, F. F. F., and Priestnall, G.: The use of photogrammetry and lidar for landscape roughness estimation in hydrodynamic studies, in: Proceedings of International Society for Photogrammetry and Remote Sensing XXth Congress, Istanbul, Turkey, 12-23 July 2004; Volume XXXV, WG III/8, 2004.

Sridhar, R., Thangaradjou, T., Kannan, L., Ramachandran, A., and Jayakumar, S.: Rapid Assessment in the Impact of Tsunami on Mangrove Vegetation of the Great Nicobar Island, J. In. Soc. Remote Sens., 34, p. 5., 2006.

Strunz, G., Post, J., Zosseder, K., Wegscheider, S., Mück, M., Riedlinger, T., Mehl, H., Dech, S., Birkmann, J., Gebert, N., Harjono, H., Anwar, H. Z., Sumaryono, Khomarudin, R. M., and Muhari, A.: Tsunami risk assessment in Indonesia, Nat. Hazards Earth Syst. Sci., 11, 67-82, doi:10.5194/nhess-11-67-2011, 2011.

Sun, G., Ranson, K. J., Kharuk, V. I., and Kovacs, K.: Validation of surface height fro shuttle radar topography mission using shuttle laser altimeter, Remote Sens. Environ., 88, 401-411, 2003.

Suppasri, A., Koshimura, S., and Imamura, F.: Developing tsunami fragility curves based on the satellite remote sensing and the numerical modeling of the 2004 Indian Ocean tsunami in Thailand, Nat. Hazards Earth Syst. Sci., 11, 173-189, doi:10.5194/nhess11-173-2011, 2011.

Szczucinski, W., Chaimanee, N., Niedzielski, P., Rachlewicz, G., Saisuttichai, D., Tepsuwan, T., Lorenc, S., and Siepak, J.: Environmental and Geological Impacts of the 26 December 2004 Tsunami in Coastal Zone of Thailand - Overview of Short and Long-Term Effects, Polish J. Environ. Stud., 15, 793-810, 2006.

Tanaka, N., Sasaki, Y., Mowjood, M. I-M., Jinadasa, K. B. S. N., and Homchuen, S.: Coastal vegetation structures and their functions in tsunami protection: experience of the recent Indian Ocean tsunami, Landscape Ecol. Eng., 3, 33-45, 2007.

Taubenböck, H., Post, J., Roth, A., Zosseder, K., Strunz, G., and Dech, S.: A conceptual vulnerability and risk framework as outline to identify capabilities of remote sensing, Nat. Hazards Earth Syst. Sci., 8, 409-420, doi:10.5194/nhess-8-409-2008, 2008.

Taubenböck, H., Wurm, M., Setiadi, N., Gebert, N., Roth, A., Strunz, G., Birkmann, J., and Dech, S.: Integrating remote sensing and social science: Urban Remote Sensing Event, 
2009 Joint, Urban Remote Sens. Event, 2009 Joint, 1-7, doi:10.1109/URS.2009.5137506, 2009.

Taylor, M.: IKONOS Planetary Reflectance and Mean Solar Exoatmospheric Irradiance, GeoEye, available at: www.geoeye.com/CorpSite/assets/docs/technicalpapers/2009/ IKONOS_Esun_Calculations.pdf (last access: 12 November 2010), 2009.

Thailand Group, International Tsunami Survey Team of Indian Ocean Tsunami Disaster: The December 26, 2004 Sumatra Earthquake Tsunami, Thailand Field Survey around Phuket, Thailand, available at: www.drs.dpri.kyoto-u.ac.jp/ sumatra/thailand/phuket_survey_e.html (last access: 10 August 2011), 2005.

Tiffert, J.: Erfassung der Tsunami people exposure an der Andamanküste Thailands: Erstellung von Datengrundlagen zur Bevölkerungs- und Touristenverteilung mit GIS \& Fernerkundung, Diploma Thesis, Christian Albrechts Universität zu Kiel, Kiel, 2010.

Titov, V. V. and Synolakis, C. E.: Modeling of breaking and non breaking long-wave evolution and run up using VTCS-2, J. Waterway Port. Coast. Ocean Eng., 121, 308-316, 1995.

Titov, V. V. and Synolakis, C. E.: Numerical modeling of tidal wave runup, J. Waterway Port. Coast. Ocean Eng., 124, 157-171, 1998.

Turner, B. L., Kasperson, R. E., Matson, P. A., McCarthy, J. J., Corell, R. W., Christensen, L., Eckley, N., Kasperson, J. X., Luers, A., Martello, M. L., Polsky, C., Pulsipher, A., and Schiller, A.: A framework for vulnerability analysis in sustainability science, P. Natl. Acad. Sci. USA, 100, 8074-8079, 2003.

UN/ISDR: Living with risk: a global review of disaster reduction initiatives, 2004 version, United Nations, New York, 429 pp., 2004.

UNDP-BCPR: Reducing Disaster Risk: A Challenge for Development: A Global Report, United Nations, New York, 2004.

Villa, F. and McLeod, H.: Environmental Vulnerability Indicators for Environmental Planning and Decision-Making: Guidelines and Applications, Environ. Manage., 29, 335-348, 2002.

Vosberg, Z.: Veränderung der Strandmorphologie an der thailändischen Andamankuste nach dem Tsunami von 2004, Bachelor Thesis, Christian-Albrechts-Universitat zu Kiel, Germany, 2010.
$\mathrm{Vu}, \mathrm{T}$. T.: Monitoring the recovery process of the disaster-affectedareas - scaling context image analysis in Geo-Grid-based solutions, The International Archives of the Photogrammetry, Remote Sensing and Spatial Information Sciences, 37, 1625-1630, 2008.

Wang, F. and Xu, Y. J.: Comparison of change detection techniques for assessing hurricane damage to forests, Environ. Monit. Assess., 162, 311-326, 2009.

Weydahl, D. J., Sagstuen, J., Dick, Ø. B., and Rønning, H.: SRTM DEM accuracy assessment over vegetated areas in Norway, Int. J. Remote Sens., 28, 3513-3527, 2007.

Whistler, W. A. and Elevitch, C. R.: Casuarina equisetifolia (beach she-oak) and C. cunninghamiana (river she-oak), ver. 2.1., in: Species Profiles for Pacific Island Agroforestry, edited by: Elevitch, C. R., available at: http://www.traditionaltree.org, 2006.

Williams, L. and Kaputska, L.: Ecosystem vulnerability: A Complex interface with technical components, Environ. Toxicol. Chem., 19, 1055-1058, 2000.

Willroth, P., Revilla Diez, J., and Arunotai, N.: Modelling the economic vulnerability of households in the Phang-Nga Province (Thailand) to natural disasters, Nat. Hazards, 58, 753-769, doi:10.1007/s11069-010-9635-1, 2011.

Willroth, P.: Quantitative vulnerability assessment for economic systems: vulnerability and the process of recovery for households and companies in Phang-Nga and Phuket Provinces in Thailand, Europäische Hochschulschriften: Reihe 5, Volks- und Betriebswirtschaft, 3407, Lang, Frankfurt, M., 2012.

Wisner, B., Blaikie, P. M., and Cannon, T.: At Risk: Natural Hazards, People's Vulnerability and Disasters, Routledge, London, 2004.

Wu, S., Qiu, X., and Wang, L.: Population Estimation Methods in GIS and Remote Sensing: A Review, Geosci. Remote. Sens., 42, 80-98, 2005.

Yanagisawa, H., Koshimura, S., Goto, K., Miyagi, T., Imamura, F., Ruangrassamee, A., and Tanavud, C.: The reduction effects of mangrove forest on a tsunami based on field surveys at Pakarang Cape, Thailand and numerical analysis, Estuarine, Coast. Shelf Sci., 81, 27-37, 2009.

Zhang, H., Lin, X., Yu, G., Huang, X., and Jing, G.: Ecological vulnerability assessment in the middle and lower reaches of the Hanjiang river basin, 3rd International Conference on Bioinformatics and Biomedical Engineering (iCBBE 2009), 11-16 June 2009, Beijing, 1-4, 2009. 